\title{
Inflammation-induced DNA damage and damage-induced inflammation: a vicious cycle
}

\section{Timea Pálmai-Pallag and Csanád Z. Bachrati*}

School of Life Sciences, University of Lincoln, Brayford Pool, Lincoln, Lincolnshire, LN6 7TS, United Kingdom

\footnotetext{
*To whom correspondence should be addressed: Csanád Z. Bachrati, School of Life Sciences, Brayford Pool, Lincoln, Lincolnshire, LN6 7TS, United Kingdom, Tel.: +44 1522 886787, e-mail: cbachrati@lincoln.ac.uk
}

Keywords: DNA damage response; inflammation; oxidative DNA damage; reactive oxygen species; cell-free DNA 


\begin{abstract}
Inflammation is the ultimate response to the constant challenges of the immune system by microbes, irritants or injury. The inflammatory cascade initiates with the recognition of microorganism-derived pathogen associated molecular patterns (PAMPs) and host cell-derived damage associated molecular patterns (DAMPs) by the pattern recognition receptors (PRRs). DNA as a molecular PAMP or DAMP is sensed directly or via specific binding proteins to instigate proinflammatory response. Some of these DNA binding proteins also participate in canonical DNA repair pathways and recognise damaged DNA to initiate DNA damage response. In this review we aim to capture the essence of the complex interplay between DNA damage response and the proinflammatory signalling through representative examples.
\end{abstract}

\title{
1. Aetiology and molecular consequences of inflammation
}

Inflammation, from the latin inflammare: set on fire, in mammals is the natural defence mechanism of the immune system in response to the constant challenges it is exposed to including injury, toxins and microorganisms, low level cosmic or medical quality radiations (X-ray, $\gamma$-irradiation or UVA/B), drugs and air pollutants (e.g. asbestos or cigarette smoke) ${ }^{1,2 *}$. Inflammation is a hallmark of aging and many chronic diseases such as obesity, Chron's disease, Parkinson's disease and autoimmune diseases just to name a few ${ }^{3-7}$.

*Additional on-line references are marked by superscript numbers 
The first phase of a complex defence mechanism is acute inflammation instigated by the infiltrated peripheral polymorphonuclear leukocytes (neutrophils), granulocytes (eosinophils) and tissue resident phagocytes (macrophages) at the site of insult. The pro-inflammatory signal is transmitted through the PRRs that can identify danger through DAMPs (e.g. ROS, circulating DNA fragments), cytokines or chemokines released by the damaged tissue or PAMPs from pathogens $[1]^{8}$. The initial role of these cells is to remove the invading pathogen and initiate tissue repair ${ }^{9}$.

One of the major defence mechanisms of the activated neutrophils and macrophages is the production of a vast spectrum of endogenous reactive oxygen (ROS) and nitrogen (RNS) species ${ }^{10}$ in a process termed "respiratory burst" ${ }^{11}$ (see below). However, ROS, as well as the more stable and less reactive by-product of ROS production, hydrogen-peroxide $\left(\mathrm{H}_{2} \mathrm{O}_{2}\right)$, are more than toxic products of respiratory burst, they are also effectors for a plethora of signalling pathways inducing innate and adaptive immune cell recruitment, proliferation, tissue healing, cell survival or apoptosis ${ }^{12-14}$. As a secondary messenger ROS are essential contributors to the signalling cascade of receptors (e.g. members of the Toll-like [TLRs] or Nucleotide-binding oligomerisation domain [NOD]-like receptors [NLRs]) that induce pro-inflammatory innate immune response via an array of functionally diverse down-stream signalling elements (e.g. NFKB, STAT1, IRF3 and caspase-1 activation) [2] ${ }^{15-20}$.

Inflammation is self-limiting and normally subsides following the removal of the insulting particles and completion of tissue repair. However, if the loss of tissue homeostasis is prolonged it may ultimately lead to chronic inflammation with increased recruitment of macrophages, enhanced senescence and suspended apoptosis, unregulated growth and tissue repair. The overwhelming persisting ROS production by inflammatory cells damages macromolecules (DNA, as well as RNA, lipids, carbohydrates and proteins) of the host cells ${ }^{21,22}$ inducing genomic instability and tipping the balance of the antitumour activity of ROS to a tumour promoting one. Chronic inflammation is viewed as a susceptibility factor for many chronic diseases including asthma, cardiovascular, autoimmune, neurodegenerative and age-related disorders ${ }^{23-30}$ and cancer ${ }^{31-33}$.Oxidative burst- 
produced inflammatory ROS damage both nuclear (nuDNA) and mitochondrial (mtDNA) DNA causing genome instability and loss of homeostasis. Mammalian cells and the immune system have evolved an arsenal of receptors recognising molecules of pathogen- or host-origin, including DNA. Damaged host DNA, similar to bacterial DNA, signals danger and induces a wealth of signalling pathways to induce DNA damage response, DNA repair, inflammatory and immune response or cell death to restore tissue homeostasis and maintain host genomic integrity and survival.

\subsection{Generation of inflammation-induced ROS and RNS}

The chemical components of inflammatory response are ROS and RNS, molecules with free radicals (containing one unpaired electron) or other non-radical oxidants generated from oxygen or nitrogen

${ }^{14}$. Oxidative stress mediating ROS can typically arise from exogenous sources such as UVA or $\gamma$ irradiation, drugs, heavy metals ${ }^{34-36}$, or from endogenous sources e.g. oxidative metabolism, apoptosis, bystander cells or enzymatic activity ${ }^{31,37-39}$. Extracellular ROS and RNS are produced by migrating neutrophils and macrophages at the site of injury or inflammation, while the intracellular sources are mostly biochemical processes through enzymatic reactions or autooxidation related to oxidative metabolism ${ }^{40}$. An array of oxidants is generated by neutrophils and macrophages at the site of infection including superoxide $\left(\mathrm{O}_{2}{ }^{*-}\right), \mathrm{H}_{2} \mathrm{O}_{2}$, hypochlorous acid $(\mathrm{HOCl})$, nitric oxide (NO*) and nitrogen dioxide radicals $\left(\mathrm{NO}_{2}{ }^{*}\right)$. These reactive species mostly arise from the enzymatic action of NADPH oxidases (NOXs), SOD, MPO and nitric oxide synthase (NOS) or non-enzymatic homolytic scissions, respectively.

Upon activation of neutrophils and macrophages, membrane bound NADPH oxidases (NOXs) are assembled in the phagosomal, endosomal or cellular membrane (NOX2) [3] ${ }^{41}$, or in the mitochondrial membrane (Complex I and III in the mitochondrial respiratory chain). NOXs catalyse the conversion of NADPH to NADP ${ }^{+}$while leaking one electron that can be captured by dissolved $\mathrm{O}_{2}$ to produce $\mathrm{O}_{2}{ }^{*-}$, which is subsequently converted to additional anti-microbial and cytotoxic ROS. The $\mathrm{O}_{2}{ }^{*-}$ is released to the cytosol or the extracellular milieu where it is protonated to $\mathrm{H}_{2} \mathrm{O}_{2}$ and $\mathrm{O}_{2}$ by 
superoxide dismutase (SOD) ${ }^{42,43} \cdot \mathrm{H}_{2} \mathrm{O}_{2}$ diffuses within the cell and through the aquaporins crosses the membrane into the extracellular space. Outside the cells it can travel long distances, which makes it a distant effector of phagocytic cellular killing ${ }^{44}$. Hence, it is also recognised as a distant effector of phagocytes when transformed to more potent oxidising radicals by myeloperoxidase (MPO) ${ }^{45,46} . \mathrm{H}_{2} \mathrm{O}_{2}$ is the substrate of MPO producing $\mathrm{HOCl}$ in neutrophils [4] ${ }^{47}$, or $\mathrm{HOBr}$ in eosinophils [5]. $\mathrm{H}_{2} \mathrm{O}_{2}$ is highly stable and less electrophilic in vivo, however, is also a source of more reactive hydroxyl radicals $\left(\mathrm{OH}^{*}\right)$ when it is reduced in the Fenton reaction by ferrous or copper ions ${ }^{14,48,49}$.

The enzyme responsible for NO* production in macrophages and less abundantly in neutrophils is inducible nitric oxide synthase (iNOS) or i-mtNOS in the mitochondria [6] ${ }^{50}$. Electron leaking from NADPH via NOS-mediated oxidation of L-arginine can also produce $\mathrm{O}_{2}{ }^{*-}$. The reaction of $\mathrm{NO}^{*}$ with $\mathrm{O}_{2}{ }^{--}$generates peroxynitrite (ONOO$\left.{ }^{-}\right) . \mathrm{ONOO}^{-}$is highly unstable and quickly autooxidates to nitrous anhydrate $\left(\mathrm{N}_{2} \mathrm{O}_{3}\right)$ or converted to $\mathrm{OH}^{*}$ and $\mathrm{NO}_{2}{ }^{*} . \mathrm{NO}_{2}{ }^{*}$ and carbonate radical anion $\left(\mathrm{CO}_{3}{ }^{*}\right)$ are the by-products of the reaction of $\mathrm{ONOO}^{-}$with $\mathrm{CO}_{2}$ followed by homolysis. Neutrophils also contribute to the $\mathrm{NO}_{2}{ }^{*}$ pool via MPO-mediated reduction of nitrite $\left(\mathrm{NO}^{2-}\right)$ to $\mathrm{NO}_{2}{ }^{*}[7]^{46,51,52}$.

Under non-inflammatory conditions, low level ROS are intracellular signal transducers contributing to physiological activation of adaptive mechanisms maintaining cellular homeostasis. Low concentration of $\mathrm{NO}^{*}$ has been observed to promote cell survival and proliferation, while nonphysiological levels can induce DNA damage, cell cycle arrest and apoptosis ${ }^{53}$. Controlling nonactivated cellular ROS levels within physiological range is the delicate balance of the catalytic and scavenger action of a wealth of enzymatic and non-enzymatic (small molecule antioxidants) reactions. Enzymes catalysing ROS metabolism include SOD, catalases, glutathione peroxydases, and thioredoxin, glutathione, methionine sulphoxide or peroxinitrite reductases ${ }^{54-57}$, while ascorbate, oxaloacetate and pyruvate are a few examples of small molecule antioxidants ${ }^{13,58,59}$. 


\subsection{Mutator ROS: ROS-induced DNA damage and repair}

The spectrum of genotoxic effects of ROS and RNS are ranging from nucleobase modification such as oxidation $\left(\mathrm{OH}^{*}, \mathrm{HOCl}\right)$, halogenation $(\mathrm{HOCl})$, alkylation, methylation, nitration $\left(\mathrm{N}_{2} \mathrm{O}_{3}, \mathrm{ONOO}^{-}\right)$, depurination and deamination, and abasic sites that can be present as isolated tandem or clustered lesions. In addition to this, more complex modifications of the DNA structure can also be catalysed by these chemical mediators of inflammation (inter- and intra-strand crosslinks, DNA-protein crosslinks, single strand breaks (SSB) and double strand breaks (DSB) [8] ${ }^{60,60-62}$. In addition, ROS can inhibit key proteins of the DNA repair machinery ${ }^{63}$. The balance between ROS induced DNA damage and repair is responsible for the relatively low level of lesions in normal cells and tissues [9]. However, this rate of damage increases with age, chronic diseases or cancer [10] ${ }^{64,65}$.

Isolated oxidative DNA lesions and abasic sites are repaired with relatively high efficiency via base excision repair (BER) ${ }^{66-68}$, while nucleotide excision repair (NER) removes intrastrand crosslinks ${ }^{69}$ and bulky nucleotide lesions. Mismatched bases and small insertion/deletion loops are repaired by mismatch repair (MMR). The pathway choice to repair DSBs depends on the cell cycle state and can utilise homologous recombination (HR) or non-homologous end joining (NHEJ). Furthermore, DSBs (induced by e.g. $\gamma$-irradiation) are repaired by NHEJ ${ }^{70,71}$ and replication-induced DSBs are repaired by $\operatorname{HR}[11]^{72}$.

\subsubsection{Isolated single nucleobase lesions, clustered DNA damage, SSB and DSB}

Inflammation-mediated halogenisation by $\mathrm{HOCl}$ or $\mathrm{HOBr}^{73}$ and nitration by $\mathrm{N}_{2} \mathrm{O}_{3}{ }^{74-79}$ can damage all four nucleotides in vivo giving rise to an abundant variety of nucleobase lesions. From all four canonical nucleotides, the most frequently identified oxidised guanine products in vivo are 8-oxodG and FapydG (2,6-diamino-4-hydroxy-5-formamidopyrimidine), while the most abundant oxidised pyrimidine lesions are thymine glycol (Tg; 5-,6-dihydroxy-5,6dihidrothymidine) and cytosine glycol (5-,6-dihydroxy-5,6dihidrocytosine) ${ }^{1,60,61,80,81}$. In addition to the above, $\mathrm{OH}^{*}$-mediated hydrolysis of 
the deoxyribosyl moiety can result in SSBs ${ }^{82}$. Abasic sites, inter- and intrastrand G-G/G-A crosslinks can arise from nitrosation of purines ${ }^{74}$; while oxidised guanines can lead to 8-oxodG:dC or 8oxodG: $d A$ pairing, the latter leading to $G \rightarrow T$ transversions ${ }^{83}[8]$.

Apart from direct nucleotide lesions generated by inflammatory ROS, secondary mutagenic radicals (aldehydes, epoxides, lipid hydroperoxides) can also arise from ROS-mediated oxidation of other cellular macromolecules and can induce further DNA lesions ${ }^{84,85}$. Clustered DNA lesions or non-DSB clusters are two or more DNA lesions within one helical DNA turn, which can be either on one strand or on both strands of the DNA helix (tandem or bistranded, respectively). Clustered DNA lesions are almost exclusively generated by ionizing radiation rather than inflammatory ROS, however, it is also reported that single pyrimidine radicals generated by reaction with $\mathrm{OH}^{*}$ can attack the complementary or neighbouring purine bases ${ }^{86,87}[8]$.

Typically, non-ionising radiation mediated oxidative stress induces SSBs, while DSBs arise as secondary lesions. Incomplete repair of a single lesion by BER (typically a nucleobase lesion or an abasic site generated by the AP endonuclease or glycosylase and more frequently by the long-patch BER) or by the NER pathways can induce SSBs and two adjacent SSBs (essentially arising from the repair of two bistranded clustered lesion) can lead to a DSB ${ }^{88}$. When the replication fork collides with unrepaired abasic sites or single strand breaks it can results in collapsed replication forks and DSBs (replication induced DSB) ${ }^{72,89}$.

\subsection{2. mtDNA damage}

The circular mtDNA constitutes $1 \%$ of total cellular DNA, is of symbiotic bacterial origin, and compared to nuDNA has a very different molecular organisation and regulation. mtDNA has no histones and the methylation of $\mathrm{CpG}$ repeat motifs is under-represented, therefore it is particularly vulnerable to damage by endogenous ROS generated by the oxidative electron transport chain during ATP synthesis ${ }^{90-92}$. The major nascent mitochondrial ROS molecule is $\mathrm{O}_{2}{ }^{*}$, which is quickly dismuted to $\mathrm{H}_{2} \mathrm{O}_{2}$. Under physiological conditions $\mathrm{O}_{2}{ }^{*-}$ and $\mathrm{H}_{2} \mathrm{O}_{2}$ are considered less reactive to 
mtDNA directly than the $\mathrm{OH}^{*}$ radicals generated from $\mathrm{H}_{2} \mathrm{O}_{2}$ in the Fenton reaction ${ }^{93,94}$. Due to the abundance of the GC-rich repeats e.g. in the ribosomal genes, the most frequent oxidative DNA adducts are 8-oxodG ${ }^{95}$, however, thymine glycol is also frequent ${ }^{96,97}$. Additional mtDNA lesions include abasic sites (from $\mathrm{OH}^{*}$-mediated hydrolysis), cytosine alkylation by S-adenosylmethionine $(\mathrm{SAM}){ }^{95}$, replication-mediated mismatch of modified nucleotides ${ }^{98}$ and repair- or replicationinduced SSBs ${ }^{99}$ or DSBs ${ }^{100}$ [12]. Abundant expression of mitochondrial NO* and secondary radicals are also responsible for mtDNA damage.

The most active pathway in the mitochondria to repair oxidative mtDNA lesions is BER ${ }^{101}$. SSBs are repaired by the joined BER/SSBR (single strand break repair) pathway ${ }^{102}$ while DSBs are by HR, albeit at low frequency ${ }^{103,104}$, or with NHEJ [13]. mtDNA degradation is another pathway to eliminate unrepaired oxidative DNA lesions ${ }^{93}$, which is supported by the abundant cellular copy number of mtDNA and observations of cellular tolerance to extensive mtDNA loss in vitro ${ }^{105}{ }^{106}$ and in vivo ${ }^{107}$ ${ }^{108,109}[13]$.

\section{Oxidised DNA as a pro-inflammatory signal}

Inflammation and ROS-mediated damage modulates the DNA damage response signalling and repair pathways resulting in an increase in expression of genes involved in repair and the inflammatory response ${ }^{110}$. On the other hand, ROS can directly damage or inhibit proteins of these processes as well ${ }^{111,112}$. In chronic inflammation, persistently high ROS level, reduced repair efficiency and dysfunctional mitochondrial respiration can lead to the accumulation of DNA damage ${ }^{113}$. If oxidative DNA lesions are unrepairable or repair is incomplete, prolonged DNA damage induces permanent cell-cycle arrest, senescence, eventually apoptosis or necrosis, during which DNA enters the degradation pathway. Under normal physiological circumstances DNA is sequestered in the nucleus and the mitochondria away from immune surveillance. Upon apoptosis $[14,15]^{114}$ necrosis or tissue damage fragmented cellular DNA can enter the vascular circulation and the intracellular space, 
however, it is not recognised as antigenic for the unchallenged immune system. Failed clearance of apoptotic debris, excess circulating extracellular DNA (also known as cell free DNA; ecDNA/cfDNA) from necrosis or tissue damage, and increased level of DNA modifications are stimuli for immune response and inflammatory pathways, and pathological processes such as atherosclerosis [16], deep vein thrombosis [17], thrombotic microangiopathies [18], primary Sjögren's syndrome or systemic lupus erythematosus (SLE) [19] ${ }^{115}$. DNA is present in the extracellular milieu (ecDNA) and the vascular system of healthy as well as diseased individuals. Increase in its concentration and the level of oxidative damage correlates with tissue damage and disease severity. It is important to note that normal physiological processes such as ageing, stress and exercise can also lead to increased ecDNA levels [20] ${ }^{116,117}$.

There are two sources of circulating ecDNA: 1) virtosomes; newly synthesised DNA/RNA/lipopolysaccharide complexes from living cells [21] or 2) cell death; apoptosis, necrosis and oncosis [15] ${ }^{118}$. Circulating ecDNA can be taken up by neighbouring or distant cells and could act as a messenger to exert biological bystander effect [22] ${ }^{119}$.

The 8-oxodG content of genomic DNA (gDNA) in necrotic cells is enriched and its concentration in the ecDNA pool is elevated by oxidative stress or disease [23] ${ }^{120}$. Serum from patients with chronic diseases contains high levels of cell free oxidamaged DNA [24], while mice treated with antigenic oxidised gDNA (gDNA ${ }^{\text {ox }}$ ) show induced inflammation and high anti-DNA ${ }^{\text {ox }}$ antibody levels [25]. Furthermore, similar to oxidised extracellular DNA (ecDNA ${ }^{\circ \mathrm{x}}$ ) released from damaged cultured cells [26] ${ }^{120}$, gDNA $^{\text {ox }}$ generated in vitro [22] is a stress signal and can induce ROS production, causes decreased expression, nuclear localisation and transcription of NFKB in cultured fibroblasts; DNA damage, apoptosis or adaptive response in cells at sites far from the initial oxidative stress. This suggests that gDNA ${ }^{\text {ox }}$ is a potential mediator of bystander effect that is observed following damage from both physical (irradiation) and chemical (ROS) sources $[22,23,26]^{120,121}$. Low-LET radiation also induces ROS-mediated oxidative damage and inflammation in normal non-irradiated tissues [27] 
122,123. Naïve cells exposed to either ecDNA from irradiated cells or gDNA extracted from $\mathrm{H}_{2} \mathrm{O}_{2}$ stressed cells show spatial and structural rearrangement of chromosomes within the nucleus, facilitating repair and transcription of ribosomal genes and genes involved in repair- and signalling processes [28].

\subsection{Oxidised mtDNA as a stress signal}

Circulating mtDNA is passively released to the extracellular space together with other mitochondrial macromolecules (e.g. lipids, formyl-peptides) by direct injury to tissue or programmed cell death mechanisms ${ }^{124,125}$, and is present in measurable amounts with higher 8-oxodG content relative to nuDNA $[23,29]$. The importance of mtDNA in host defence is demonstrated by its active release via another immune response mechanism, called neutrophil extracellular traps (NETs): mtDNA and ROS are launched by activated eosinophils [30] ${ }^{126}$ and neutrophils [31] ${ }^{127,128}$ in response to bacterial lipopolysacharide induced IFN- $\gamma$ and IL-5 ${ }^{129}$.

The immune response to mitochondrial DAMP (e.g. mtDNA and ROS) is similar to PAMP induced PRR signalling and inflammatory immune response. One might surmise that despite the two billion year old symbiosis, mitochondria still possess immunogenic properties reminiscent of bacteria, and together with ROS these mitochondrial signals are an additional level in host immune defence (stress induced adaptive response) to maintain or restore homeostasis or if it is beyond that induce cell death. This may not be too far-fetched from the bacterial SOS response to ROS-induced damage from host cells. Invading bacteria activate pathogen recognition receptors, incite chronic inflammation and host DNA damage to hijack host DNA repair processes in order to repair their own DNA and gain bacterial resistance and survival. However, prolonged inflammation inhibits DNA repair, eventually leading to cancer. Helicobacter pylori infection downregulates MMR and BER and consequently induces carcinogenesis [32] ${ }^{130-132}$, especially if $H$. pylori infection is associated with underlying metabolic syndromes such as diabetes or obesity [33] ${ }^{133}$. Exposure of cultured MEFs and HCT116 cells to oxidative stress showes much higher frequency of SSBs, but only a marginal increase 
of 8-oxodG load in mtDNA [34]. On the other hand 8-oxodG level is increased in the fragmented mtDNA population in tissues $[23,29]$, which implicates that if repair is overwhelmed mtDNA degradation is a potential pathway to maintain mitochondrial genomic integrity by clearing out damaged copies. Released extracellular or intracellular oxidamaged mtDNA (mtDNA ${ }^{\text {ox }}$ ) fragments than act as mediators of immune response via DAMP activated TLR9 receptor signalling (see below). A large body of in vitro and in vivo data supports that 8-oxodG DNA fragments with high GC content promote local as well as distant inflammation. Exposure of cultured murine macrophages to such DNA induces TNF $\alpha$ secretion [35], while bystander effect has been demonstrated in a murine model: when the liver was injected with isolated mtDNA it also induced lung inflammation [36]. mtDNA binding to TLR9, subsequent p38MAPK phosphorylation and IL-8 secretion are diminished in vivo in cultured neutrophils that are incubated with oligonucleotides complementary to $\mathrm{CpG}$ repeats of mtDNA [36]. Bacterial-like non-methylated CpG rich mtDNA, therefore, can influence inflammation that is found to increase lung injury and arthritis in murine models in vivo, which is further enhanced by oxidative mtDNA damage $[36,37]$. Furthermore, cell free oxidised mtDNA is found in arthritic joint fluids [37] ${ }^{134}$.

Oxidative stress induces elevated mitochondrial respiration and translocation of thioredoxininteracting protein (TXNIP) from the nucleus to the mitochondria [38]. In the mitochondria TXNIP inhibits the antioxidant thioredoxin 2 (TRX2) [39], which leads to mtDNA damage, elevated ATP synthesis, amplified ROS production and dysfunctional mitochondria to culminate in inflammation or cell death ${ }^{135-137}$ [40]. A genuine cellular response to eliminate dysfunctional mitochondria is mitophagy (mitochondrial autophagy) ${ }^{138}$, which blocks NLRP3 inflammasome activation and the inflammatory response [2,41]. NLRP3 (NLR family, pyrin domain containing 3 ) is a molecular monitor of the metabolic status of mitochondria and the cytosol for DAMPs and PAMPs [42] ${ }^{20}$ e.g. various radiation-generated ROS [43], asbestos and silica [44], $\beta$-amyloid plaques [45], extracellular ATP [46], oxidised mtDNA [47] and double-stranded RNA [48]. Depletion of mtDNA also inhibits inflammasome activation [41]. In the absence of mitophagy, augmented ROS can activate the 
opening of mitochondrial permeability transition pores (mPTP) and the release of cytochrome c, ATP and $\mathrm{Ca}^{2+}$ to the cytosol. This in turn induces the intrinsic (mitochondrial) apoptotic pathway through the activation of the apoptosome ${ }^{138,139}$ and a subsequent release of ROS, TXNIP, non-oxidised and 8oxodG rich oxidised mtDNA to the cytosol, which then directly bind to NLRP3 $[2,41,47]^{18,140}$. Priming of the NLRP3 inflammasome requires a pro-inflammatory signal likely provided by ROS ${ }^{141}$. Oxidamaged mtDNA binds to the pyrine domain of NLRP3, which then interacts with the cytosolic apoptosis-associated spec-like protein (ASC) component and induces the assembly and activation of the NLRP3-ASC adaptor-procaspase-1 complex (inflammasome). The active NLRP3 inflammasome relocates from the ER to the perinuclear space and binds to the mitochondrial outer membranes via the mitochondria-associated adaptor molecule, MAVS (mitochondrial antiviral signalling) [2] ${ }^{142}$. Mitochondrial membrane-bound NLRP3 instigates inflammatory caspase-1 autocatalysis ${ }^{143}$, which interlinks pathways of cell death and the inflammatory response ${ }^{139}$ (Fig. 1A). Active caspase-1 enhances proteolytic cleavage and secretion of pro-inflammatory cytokines (IL-1 $\beta$, IL-33 and IL-18) [42] ${ }^{144,145}$, which in turn result in the expression of TNF $\alpha$ and IFN ( $\alpha / \beta$ and $\left.\gamma\right)$ instigating further immune cell recruitment. These pro-inflammatory cytokines activate the IL-1 or TNF receptors, and downstream NFKB signalling ${ }^{146}$. Activated caspase-1 also instigates the pyroptosis pathway: an inflammatory form of apoptosis characterised by cellular 'rapture' that releases its pro-inflammatory content, including oxidised DNA fragments ${ }^{124,147}$. NLRs are also involved in and regulate mtDNAmediated inflammation and apoptosis in concert with TLR9 $[47,49]$.

Recent in vivo and in vitro studies show that intact or oxidised mtDNA is a danger signal [1] ${ }^{129,148}$, and induces pro-inflammatory cytokine (TNF $\alpha$, IL-6 and IL-10) expression. This in turn promotes recruitment of activated macrophages, age related low level inflammation [20], or sepsis-like non infection associated, sterile SIRS (systemic inflammatory response syndrome) via the DAMP activated TLR9/NFKB pathway following trauma and lung injury [50]. However, other DNA sensors are likely involved in mtDNA and ROS mediated damage signalling [26] ${ }^{120}$ as well. 
In vivo and in vitro studies show that the effect of mtDNA as a damage signal is much more adverse than that of nuDNA [1] ${ }^{148,149}$. As protein coding in mtDNA is restricted to elements of the electron transport chain, many functions (replication, repair and transcription) in mitochondria rely on products encoded in the nuclei that are transported to the mitochondria ${ }^{150,151}$. As a consequence, nuDNA damage is also an important contributing factor to dysfunctional mitochondria ${ }^{152}$.

\section{Transduction of damaged DNA induced stress signal}

Several different proteins have been identified to date (including MRE11 ${ }^{153}$, PARP-1, Ku70, DNA-PK ${ }^{154}$ IFI16 ${ }^{155}$, DDX41 ${ }^{156}$, RNA Pol-III ${ }^{157}$, cGAS $^{158}$, DAl, HMGB1, AIM2 ${ }^{159}$, RIG-1, TLR9 and STING ${ }^{160-162}$ ) [51] ${ }^{163}$, which bind pathogen- or host derived DNA (originating from either the mitochondria or nuclei in response to cellular stress) and initiate defensive immune-response via NLRs, TLRs or RLRs (retinoic acid inducible gene-1 [RIG-1]-like receptors) mostly in a cell-type specific fashion. These sensors bind dsDNA in a non-differentiating manner only showing some preferences to non-oxidised or 8-oxodG rich DNA structures [47]. Further investigations are required to identify a specific DNA structure for pathogen derived DNA PAMPs ${ }^{164}$ or conditions and conformations (emerged from its processing) that designate host-derived DNA ${ }^{165}$ as DAMPs.

\subsection{TLR9}

Toll-like receptor 9 (TLR9) is present in cellular, nuclear and phagosomal membranes of innate immune cells and its expression is elevated during inflammation and starvation [22]. Nonmethylated bacterial CpG-DNA from phagocytosis and mtDNA with the same properties are ligand to TLR9 via the extracellular high mobility group protein-1 (HMGB1). 8-oxodG enriched ecDNA ${ }^{\text {ox }}$ from tissue damage, cell death (pyroptosis) or mitochondrial release as DAMPs are preferred TLR9 ligands [52] ${ }^{166,167}$, while extracellular histones are direct TLR9 ligands [53]. Ligand activation followed by the binding of the signalling adaptor MYD88 to TLR9 ${ }^{168,169}$ induces TLR9 translocation from the ER to the endosomes [54]. MYD88 is also a signalling adaptor of the cytokine receptor IL-1R [55] linking the 
TLR-dependent and TLR-independent inflammatory response pathways. The downstream effect of TLR9/MYD88 stimulation leads to IKB degradation and nuclear translocation of the NFKB transcription factor and the simultaneous phosphorylation of p38MAPK. This subsequently induces the synthesis and release of IFN- $\gamma$ and TNF $\alpha$. NFKB, in combination with other transcription factors e.g. AP-1, IRFs and CREB, induces the expression of proteins like additional pro-inflammatory cytokines (IL-1 $\beta$, IL-6, IL-10, IL-18), NOX2, NLRP3, TRX2, TRX3 to regulate innate (monocyte recruitment) and adaptive ( $T$ - and $B$ cell activation) immune response, local inflammation $[36,50]$ 170,171, inflammation in distant cells or organs (bystander effect) [36] and senescence, as well as proliferation, tissue repair and survival [49] ${ }^{172-176}$ (Fig. 1B).

Accumulation of non-degraded mtDNA leaking from overwhelmed autophagy induces TLR9 expression and TLR9-mediated inflammation [56]. Similarly, ecDNA from cancer patients induces TLR9 expression in mesenchymal stem cells [26], while TLR9 inhibitors decrease damaged ecDNA induced TLR9-mediated DNA damage response (chromosome remodelling, nuclear rearrangement, rRNA expression) in the bystander cells [22].

\subsection{AIM2}

Similar to phagolysosomal pathogen entry to the cytosol, intracellular dsDNA and mtDNA can bind and activate another type of inflammasome, AIM2 (Absent in melanoma-2) and induce caspase-1 mediated activation and secretion of IL-1 $\beta$ and IL-18 in addition to caspase-1 induced pyroptosis [57] ${ }^{177,178}$ (Fig. 1A). Rathinam and co-workers also showed that cytosolic dsDNA induces type I IFN and AIM2 expression. This suggests that oxidised ecDNA that escapes degradation following entry into the cell via phagosomes can induce cell death and inflammation. However, in macrophages, nonoxidised DNA preferentially activates AIM2 [57], while oxidised mtDNA induces NLRP3 inflammasome assembly and both induce IL-1 $\beta$ secretion [47]. 


\subsection{STING}

The presence of 8-oxodG lesions alleviates the susceptibility of DNA to degradation by the TREX1 exonuclease [58], and as a consequence it accumulates to induce immune response. Elevated ecDNA level from increased apoptosis or NETs from dying neutrophils with defect in lysosomal DNase activity are characteristic for SLE [59]. Elevated ROS production induces NET formation ${ }^{179}$, hence ecDNA in SLE accumulates 8-oxodG lesions that are sensed by STING (stimulator of IFN genes) and induces IRF signalling [58]. Following dsDNA stimuli STING relocates from the ER membrane to perinuclear endosomal compartments and forms a complex with TANK-binding kinase 1 (TBK1) [60] (Fig. 1C). The STING-TBK1 complex activates IKK to induce the NFKB or IRF3 pathways in a TLRindependent manner and induces Type I IFN expression and release, thus overstimulation of antiviral and inflammatory innate immune responses via membrane IFN-receptor (IFNAR) in neighbouring cells and lymphocytes. Type I IFN-mediated receptor activation initiates the Janus kinase (JAK) signal transducer and the STAT (signal transducer and activator of transcription) pathway stimulating the expression of different antiviral genes ${ }^{180,181}$.

dsDNA also activates translocation of STING to the apoptosome where it associates with TBK1 and interacts with autophagy-related proteins (Atg-9a) promoting autophagy [61]. Although STINGdependent IFN- $\beta$ production is proven to be stimulated by synthetic poly(dG:dC) and dsDNA in MEFs, binding and colocalisation of STING to DNA were not shown suggesting that STING is not a DNA binding protein [60]. However, Abe and co-workers shown low affinity dsDNA binding to STING homodimers [62]. Upstream dsDNA binding molecules that induce the STING-TBK1-IRF3 pathway are IFN-inducible protein 16 (IFI16) [63] and DEAD-box polypeptide 41 (DDX41) [64], in addition to the recently identified cyclic GMP-AMP (cGAMP) synthase (cGAS) (Fig. 1C). cGAS binds and activates STING via the secondary messenger cGAMP and triggers NFKB and IFN response [65] ${ }^{182,183}$. The bacterial cyclic di-adenylate monophosphate (c-di-AMP) and cyclic di-guanylate monophosphate (c-

di-GMP) are directly sensed by STING [66 ${ }^{184,185}$ as well as via DDX41 [67]. The reduced IFN- $\beta$ level in 
Sting $^{-/-}$MEFs to synthetic poly(dA:dT) dsDNA was accounted for an additional Type I IFN response that is independent of both TLR and STING, and mediated by the dsDNA induced innate immune signalling receptor RIG-1 [60]. RIG-1, a member of the RLR family, is a dsRNA receptor that also triggers antiviral response to dsDNA ${ }^{186-188}$.

\subsection{DNA damage sensor and repair proteins in inflammatory immune response}

Damage to the DNA induces a cascade of actions commonly termed the DNA damage response (DDR). DDR includes the activation of different transcription programs, cell cycle checkpoints to induce transient or permanent cell cycle arrest (senescence), activation of specific repair pathways and apoptosis if repair fails. While the dsDNA-mediated immune-response pathways have been well characterised, there are still new alliances being discovered between DNA damage sensors of the DNA repair pathways and DNA receptors of the immune system.

\subsubsection{MRE11}

The MRN complex, consisting of MRE11 (Meiotic recombination 11 homolog A), RAD50 and NBS1 (Nijmegen breakage syndrome 1), is one of the first proteins to sense and bind broken doublestranded DNA ends. MRE11 possesses $3^{\prime} \rightarrow 5^{\prime}$ exonuclease activity and contributes to the resection of the broken end thus facilitates and regulates HR or NHEJ depending on cell cycle ${ }^{71,189}$. The complex controls DDR via the CDK phosporylation-dependent binding of CtIP to NBS1 and facilitating the ATM dependent phosphorylation of CtIP ${ }^{190-192}$. Once activated, CtIP promotes end resection by stimulating the endonuclease activity of MRE11 in an S-phase dependent manner [68] (Fig. 1D). In addition to IFI16 and DDX41 dsDNA binding proteins, MRE11 was also implicated in stimulating dsDNA induced type I IFN mediated inflammatory signalling via the STING-dependent pathway [69]. It has been shown in MEFs and ataxia telangiectasia-like disorder (ATLD) cells treated with non-ATrich IFN stimulating DNA sequences, that MRE11 in complex with RAD50 but independent from 
NBS1, induces IFN- $\beta$ expression, and activation and translocation of STING. MRE11-mediated STING activation is not induced by pathogen-derived DNA suggesting that MRE11 rather functions in host damage response [69] (Fig. 1C). ATM activation promoted by MRE11 ultimately induces the p53 and p21 checkpoint proteins and cell cycle arrest, indicating a role of MRE11 in the control of p53 dependent apoptosis and cell-cycle regulation, and a direct link between DDR and the immune response pathways ${ }^{193}$. While p53 is considered to be a tumour suppressor, when overexpressed or in constant activation it can promote pro-tumorigenic inflammation ${ }^{194}$. Yan et al reported that in rat liver constant genotoxic stress-induced persistent DNA damage sustained elevated p53 expression and subsequently increased HMGB1 secretion, pro-tumorigenic hepatic inflammation and apoptotic hepatic injury in wild type rats, which was less severe in heterozygous $p 53^{+/-}$rats [70] ${ }^{195}$. Additionally, ATM also induces a pro-survival response via activated NFKB, which in turn accelerates DNA end resection, promotes HR, and induces BRCA2 and ATM transcription [71] (Fig. 1D).

\subsubsection{PARP-1}

Persistent unrepaired DNA lesions can cause replication fork stalling. A stalled replication fork may collapse if it is processed by endonucleases like MUS81, or if a progressing fork encounters an SSB it is converted to a DSB ${ }^{196}$. Stalled replication forks can reverse to aid template switching, replication past a lesion and replication restart. Collapsed forks can be re-built and replication reinstated through the homologous recombination repair pathway ${ }^{197,198}$. This process is initiated with endresection that is catalysed by the MRN complex. Stalled replication forks, SSBs, DSBs, DNA cross over or stem loop/cruciform structures are sensed by the DNA binding and scaffold protein poly-ADPribose polymerase (PARP-1) [72]. PARP-1 has a bipolar effect in oxidative stress-induced DDR: DNA repair and survival or necrotic cell death. PARP-1 directly binds and recruits several proteins of the major repair pathways (MRE11, NBS1 ${ }^{199,200}, \mathrm{Ku}^{201}{ }^{201}$ DNA-PK ${ }^{202}$, ATM ${ }^{203}$ ) and regulates chromatin remodelling, DNA replication and repair, and transcriptional activity of inflammatory factors ${ }^{204-206}$ (Fig. 1F). PARP-1 is also involved in caspase-1 mediated [73] or caspase-independent [74] apoptosis 
and autophagy ${ }^{207}$ [75]. PARP-1 catalyses the addition of poly (ADP-ribose) (PAR) chains to its substrate proteins and facilitates DNA repair. Persistent DNA damage induced PARP-1 overactivation results in the depletion of cellular $\mathrm{NAD}^{+}$. $\mathrm{NAD}^{+}$re-synthesis leads to the depletion of cellular ATP reserves, impaired energy metabolism, cellular and mitochondrial dysfunction and necrosis; known as PARP-suicide [76]. PARP-1 is implicated in many inflammatory diseases including diabetes ${ }^{208}$, asthma ${ }^{209,210}$, atherosclerosis ${ }^{211}$ and hepatic fibrosis ${ }^{212}$ [77]. PARP-1 directly interacts and activates (PARylation) p53, and NFKB [78] ${ }^{213,214}$, while interaction with p21 inhibits PARylation activity [72] ${ }^{215}$. In addition, PARP-1 was shown to regulate the phosphorylation of ERK1/2, p38MAPK, and c-Jun [78]. Similar to senescence, DNA damage induced PARP-1 over-activation generates an inflammatory feedback loop. PARP-1 binding to NFKB induces NFKB-mediated inflammatory immune-response by iNOS and expression of pro-inflammatory cytokines (e.g. IL-1, TNF $\alpha$ ), leading to inflammatory ROS production and persistent DNA damage [72] ${ }^{216-219}$.

\subsubsection{Ku70 and DNA-PK}

DSB is sensed by Ku70 to facilitate the Ku-dependent non-homologous DNA end-joining pathway (NHEJ), the major cell-cycle independent repair pathway of double stranded DNA breaks ${ }^{70}$. Ku70 is also implicated in the triggering of inflammatory signalling by inducing IRF1 and IRF7-mediated Type III IFN expression (IFN- $\lambda 1$ ) [79] (Fig. 1E).

DNA-dependent protein kinase catalytic subunit (DNA-PKcs) is a member of the phosphatidyl-inositol (PI3) kinase family (of which ATM and ATR are also members). DNA-PKcs is activated upon binding to the Ku70/Ku80 regulatory subunit bound to dsDNA ends. DNA-PK plays a central role in DNA repair (NHEJ) and in $\mathrm{V}(\mathrm{D}) \mathrm{J}$ recombination of programmed DNA rearrangements in lymphocyte differentiation in the nucleus ${ }^{70,220,221}$, but it also plays a role in the cytoplasm [80] 222,223. Macrophages expressing catalytic dead DNA-PKcs or siRNA knock down of DNA-PKcs showed that its activity is essential for transfected synthetic CpG oligonucleotide -induced expression of the antiinflammatory cytokine IL-10 while DNA-PKcs activity inhibits the expression of the inflammatory 
cytokine IL-12p70. It correlates with previous findings that unmethylated CpG oligonucleotides induce IL-6, IL-10, IL-12, type I IFN and TNF $\alpha$ in dendritic cells (DC), macrophages and B cells [81] ${ }^{224}$. DNA-PKcs-mediated cytosolic binding of CpG oligonucleotides is a pre-requisite for the regulation of IL-12p70 and IL-10 expression through the DNA-PKcs-ERK mediated pathway. Interestingly, the CpG oligonucleotide-liposome complex also induces IL-12p70 [80]. Nevertheless, IL-12p70 induction could also be a response of TLR4 receptor activation that is probably induced by the liposome itself. A recently described cytoplasmic function of DNA-PK is the cytoplasmic DNA-mediated activation of IRF-3 in vitro and in vivo via STING-TBK1 stimulation (Fig. 1C). DNA-PKcs directly binds cytoplasmic DNA, which is enhanced by Ku and DNA-PKcs catalytic activity is not required for IRF-3 signalling [82].

\subsubsection{HMGB1}

HMGB1 (also called alarmin) is a chromosomal scaffold protein with diverse nuclear, cytosolic and extracellular functions. In the nucleus it facilitates chromatin assembly, binding of proteincomplexes, and regulates transcription ${ }^{225}$, replication ${ }^{226}$, chromatin remodelling upon DNA damage 227,228 and DNA repair. HMGB1 can bind to different DNA structures in vivo and promote the NER ${ }^{229}$, $\mathrm{BER}^{230,231}$ and $M \mathrm{MMR}^{232}$ pathways. HMGB1 enhances the binding and the activity of Ku and DNA-PK at the DSB ends in NHEJ ${ }^{233}$ and is implicated in $V(D) J$ recombination ${ }^{234}$ [83]. In addition to recognising specific DNA structures: supercoiled, hemicatenated, single stranded, B- and Z-DNA, four-way junction, triplex DNA, looped structures and DNA mini circles [83] ${ }^{166,235}$, HMGB1 has strong binding affinity to damaged DNA sequences like UV treated oxidised DNA [84] and to CpG DNA. HMGB1 promotes TLR9 translocation to the endosomes and the HMGB1-CpG DNA complex induces TLR9 mediated IL-6, IL-12 and TNFa secretion in macrophages and DCs [85] (Fig. 1B). In response to starvation induced mitochondrial ROS mediated oxidative stress, HMGB1 actively translocates to the cytosol to inhibit apoptosis and to promote autophagy and survival. Intriguingly, this process is hijacked by tumour cells by overexpressing HMGB1 $[86]^{236}$. As an extracellular DAMP, it induces proinflammatory signalling when released by activated immune cells [87] ${ }^{237,238}$ or necrotic non-immune 
cells [88] ${ }^{239}$. It acts as a cytokine: stimulates migration of immune cells in complex with CXCL12 [89], secretion of pro-inflammatory TNF $\alpha$, IL-1 and IL- $6{ }^{240}$, and induces secondary delayed inflammatory response [90]. HMGB1 signals through the cell surface RAGE receptor on immune and non-immune cells to activate NFKB via the Ras-MAPK pathway [91], to promote tumour invasion by activating MAP kinases p38MAPK, JNKs and ERK1/2 (p44/42 MAPK) [92], and to induce NET formation via TLR4-mediated signalling [93]. Thus, HMGB1 is a contributing factor to many pathogenic conditions including sterile inflammations [94], sepsis [95] ${ }^{241}$; chronic inflammatory diseases like rheumatoid arthritis [96]; autoimmune diseases like SLE [97] and tumour development and survival [98] ${ }^{236,242}$. As a specific example: in chronic lymphocytic leukemia (CLL) plasma HMGB1 endorses proliferation of the nurse-like cells and the tumour via the RAGE-TLR9 pathway [99]. These suggest that in addition to its active release by activated innate immune cells to mediate pathogenic PAMP (GPC DNA) activated inflammatory immune response, nuclear HMGB-1 maintains DNA repair, genome integrity and promotes survival. Once DNA damage becomes prolonged and repair fails DNA-HMGB1 structures are released by necrosis and as DAMPs induce a second wave of inflammatory response that can be hijacked by tumour cells.

\section{Concluding remarks}

The link between DNA mutations, genome instability and tumour development is well established, and it is also widely recognised that chronic inflammation is a cancer susceptibility factor. Understanding the interplay between DNA damage response pathways and inflammation has dominated research in recent years. Our understanding of how the genotoxic effects of inflammation induce DNA damage response, and how factors of the DDR pathway and the PRRmediated inflammatory immune response processes interlink to maintain homeostasis have advanced significantly. It all supports the hypothesis of a global inflammation cascade propelled by ROS and DNA damage. Loss of immune homeostasis and prolonged acute inflammation generated by different sources (infection, radiation, toxins, autoimmune disease and genetic susceptibility to 
inflammation, aging, dietary factors and many more) induce ROS production, elevated ROSmediated oxidative DNA damage, reduced repair capacity launching more ROS and oxidamaged DNA (nuclear and mitochondrial) by death of damaged cells. This in turn induces secondary and subsequent inflammation in intact distant bystander cells as stress signals, which accelerates into a systemic acute inflammation or cancer. The balance between these counteracting pathways is delicate and aim to avoid chronic inflammation, loss of genomic integrity by promoting DNA repair, or induce apoptosis to eliminate cells with accumulated unrepaired pro-tumorigenic mutations. Amongst many regulatory factors, damaged DNA within the nucleus and the mitochondria, or released from dying cells seems to play a central role by signalling danger and influencing repair and inflammation-associated pathways. Hence, while developing targeted therapeutic approaches to treat inflammation-associated diseases, the complex relationship between DDR and inflammatory immune processes has to be taken into consideration.

\section{Acknowledgement}

The authors wish to express their gratitude to Dr Ciaren Graham, Prof. Paul Squires and Dr Endre Kiss-Toth for critical reading of the manuscript. Research in our laboratory is supported by the Biotechnology and Biological Sciences Research Council (BBSRC) under grant number BB/K019597/1, and is gratefully acknowledged.

\section{Figure legends}

Figure 1. Complex relationship between the inflammatory and DNA damage (DDR) response pathways. Genotoxic ROS induced DNA damage is sensed at different levels during inflammation and is a contributing factor to the pro- and anti-inflammatory immune response to restore tissue homeostasis. The cytosolic dsDNA sensor (A) AIM2 and NLRP3 inflammasomes contribute via ligand activated caspase-1 to the inflammatory catabolic NFKB pathway by post-translational cytokine 
activation, or if the damage is greater induce cell death programmes. (B) Other cytosolic DNA sensors (IFI16, DDX41, DNA-PK etc.) via activated STING-TBK1 integrate into the cytokine and interferon signalling pathways in a TLR- independent manner promoting pro-inflammatory innate immune processes. (C) The same response is instigated by dsDNA in different endosomal compartments via the membrane bound TLR9 receptor. Nuclear damaged DNA sensors induce the DDR response: (D) the MRN complex (MRE11-RAD50-NBS1) through activated ATM and (F) PARP-1 instigate cell cycle arrest via the p53-p21 axis, DNA repair processes and additional transcriptional activation of inflammatory and repair genes (Pro-ILs, Type I IFN, NLRP3, ATM etc.) via NFKB or (E) via IRF3 transduced from the Ku70/Ku80/DNA-PK complex to promote cell survival or cell death in case of persistent damage.

\section{References}

[1] Zhang Q, Raoof M, Chen Y, Sumi Y, Sursal T, Junger W, Brohi K, Itagaki K, Hauser CJ, Circulating mitochondrial DAMPs cause inflammatory responses to injury, Nature 464 (2010) 104-107.

[2] Zhou R, Yazdi AS, Menu P, Tschopp J, A role for mitochondria in NLRP3 inflammasome activation, Nature 469 (2011) 221-225.

[3] Babior BM, Phagocytes and oxidative stress, Am J Med 109 (2000) 33-44.

[4] Klebanoff SJ, Myeloperoxidase: friend and foe, J Leukoc Biol 77 (2005) 598-625.

[5] Weiss SJ, Test ST, Eckmann CM, Roos D, Regiani S, Brominating oxidants generated by human eosinophils, Science 234 (1986) 200-203.

[6] Weinberg JB, Misukonis MA, Shami PJ, Mason SN, Sauls DL, Dittman WA, Wood ER, Smith GK, McDonald B, Bachus KE, ., Human mononuclear phagocyte inducible nitric oxide synthase (iNOS): analysis of iNOS mRNA, iNOS protein, biopterin, and nitric oxide production by blood monocytes and peritoneal macrophages, Blood 86 (1995) 1184-1195. 
[7] Knaapen AM, Gungor N, Schins RP, Borm PJ, Van Schooten FJ, Neutrophils and respiratory tract DNA damage and mutagenesis: a review, Mutagenesis 21 (2006) 225-236.

[8] Cadet J, Loft S, Olinski R, Evans MD, Bialkowski K, Richard WJ, Dedon PC, Moller P, Greenberg MM, Cooke MS, Biologically relevant oxidants and terminology, classification and nomenclature of oxidatively generated damage to nucleobases and 2-deoxyribose in nucleic acids, Free Radic Res 46 (2012) 367-381.

[9] Gedik CM, Collins A, Establishing the background level of base oxidation in human lymphocyte DNA: results of an interlaboratory validation study, FASEB J 19 (2005) 82-84.

[10] Malins DC, Johnson PM, Wheeler TM, Barker EA, Polissar NL, Vinson MA, Age-related radicalinduced DNA damage is linked to prostate cancer, Cancer Res 61 (2001) 6025-6028.

[11] Thomson LH, Recognition, signaling, and repair of DNA double-strand breaks produced by ionizing radiation in mammalian cells: The molecular choreography, Mutat Res 751 (2012) $158-246$.

[12] Kazak L, Reyes A, Holt IJ, Minimizing the damage: repair pathways keep mitochondrial DNA intact, Nat Rev Mol Cell Biol 13 (2012) 659-671.

[13] Alexeyev M, Shokolenko I, Wilson G, LeDoux S, The maintenance of mitochondrial DNA integrity--critical analysis and update, Cold Spring Harb Perspect Biol 5 (2013) a012641.

[14] Suzuki N, Kamataki A, Yamaki J, Homma Y, Characterization of circulating DNA in healthy human plasma, Clin Chim Acta 387 (2008) 55-58.

[15] Jahr S, Hentze H, Englisch S, Hardt D, Fackelmayer FO, Hesch RD, Knippers R, DNA fragments in the blood plasma of cancer patients: quantitations and evidence for their origin from apoptotic and necrotic cells, Cancer Res 61 (2001) 1659-1665. 
[16] Oka T, Hikoso S, Yamaguchi O, Taneike M, Takeda T, Tamai T, Oyabu J, Murakawa T, Nakayama H, Nishida K, Akira S, Yamamoto A, Komuro I, Otsu K, Mitochondrial DNA that escapes from autophagy causes inflammation and heart failure, Nature 485 (2012) 251-255.

[17] Brill A, Fuchs TA, Savchenko AS, Thomas GM, Martinod K, De Meyer SF, Bhandari AA, Wagner DD, Neutrophil extracellular traps promote deep vein thrombosis in mice, J Thromb Haemost $10(2012)$ 136-144.

[18] Fuchs TA, Kremer Hovinga JA, Schatzberg D, Wagner DD, Lammle B, Circulating DNA and myeloperoxidase indicate disease activity in patients with thrombotic microangiopathies, Blood 120 (2012) 1157-1164.

[19] Bartoloni E, Ludovini V, Alunno A, Pistola L, Bistoni O, Crino L, Gerli R, Increased levels of circulating DNA in patients with systemic autoimmune diseases: A possible marker of disease activity in Sjogren's syndrome, Lupus 20 (2011) 928-935.

[20] Pinti M, Cevenini E, Nasi M, De Biasi S, Salvioli S, Monti D, Benatti S, Gibellini L, Cotichini R, Stazi MA, Trenti T, Franceschi C, Cossarizza A, Circulating mitochondrial DNA increases with age and is a familiar trait: implications for "inflamm-aging", Eur J Immunol(2014)

[21] Gahan PB, Stroun M, The virtosome-a novel cytosolic informative entity and intercellular messenger, Cell Biochem Funct 28 (2010) 529-538.

[22] Kostyuk SV, Tabakov VJ, Chestkov VV, Konkova MS, Glebova KV, Baydakova GV, Ershova ES, Izhevskaya VL, Baranova A, Veiko NN, Oxidized DNA induces an adaptive response in human fibroblasts, Mutat Res 747-748 (2013) 6-18.

[23] Ermakov AV, Konkova MS, Kostyuk SV, Izevskaya VL, Baranova A, Veiko NN, Oxidized extracellular DNA as a stress signal in human cells, Oxid Med Cell Longev 2013 (2013) 649747. 
[24] Hajizadeh S, DeGroot J, TeKoppele JM, Tarkowski A, Collins LV, Extracellular mitochondrial DNA and oxidatively damaged DNA in synovial fluid of patients with rheumatoid arthritis, Arthritis Res Ther 5 (2003) R234-R240.

[25] Cooke MS, Herbert KE, Butler PC, Lunec J, Further evidence for a possible role of conformation in the immunogenicity and antigenicity of the oxidative DNA lesion, 8-oxo-2'deoxyguanosine, Free Radic Res 28 (1998) 459-469.

[26] Kostyuk SV, Ermakov AV, Alekseeva AY, Smirnova TD, Glebova KV, Efremova LV, Baranova A, Veiko NN, Role of extracellular DNA oxidative modification in radiation induced bystander effects in human endotheliocytes, Mutat Res 729 (2012) 52-60.

[27] Blyth BJ, Sykes PJ, Radiation-induced bystander effects: what are they, and how relevant are they to human radiation exposures?, Radiat Res 176 (2011) 139-157.

[28] Ermakov AV, Konkova MS, Kostyuk SV, Smirnova TD, Malinovskaya EM, Efremova LV, Veiko NN, An extracellular DNA mediated bystander effect produced from low dose irradiated endothelial cells, Mutat Res 712 (2011) 1-10.

[29] Suter M, Richter C, Fragmented mitochondrial DNA is the predominant carrier of oxidized DNA bases, Biochemistry 38 (1999) 459-464.

[30] Yousefi S, Gold JA, Andina N, Lee JJ, Kelly AM, Kozlowski E, Schmid I, Straumann A, Reichenbach J, Gleich GJ, Simon HU, Catapult-like release of mitochondrial DNA by eosinophils contributes to antibacterial defense, Nat Med 14 (2008) 949-953.

[31] Brinkmann V, Zychlinsky A, Neutrophil extracellular traps: is immunity the second function of chromatin?, J Cell Biol 198 (2012) 773-783.

[32] Polk DB, Peek RM, Jr., Helicobacter pylori: gastric cancer and beyond, Nat Rev Cancer 10 (2010) 403-414. 
[33] Li Q, Zhang J, Zhou Y, Qiao L, Obesity and gastric cancer, Front Biosci (Landmark Ed) 17 (2012) 2383-2390.

[34] Shokolenko I, Venediktova N, Bochkareva A, Wilson GL, Alexeyev MF, Oxidative stress induces degradation of mitochondrial DNA, Nucleic Acids Res 37 (2009) 2539-2548.

[35] Yoshida H, Nishikawa M, Kiyota T, Toyota H, Takakura Y, Increase in CpG DNA-induced inflammatory responses by DNA oxidation in macrophages and mice, Free Radic Biol Med 51 (2011) 424-431.

[36] Zhang $Q$, Itagaki $K$, Hauser $\mathrm{CJ}$, Mitochondrial DNA is released by shock and activates neutrophils via p38 map kinase, Shock 34 (2010) 55-59.

[37] Collins LV, Hajizadeh S, Holme E, Jonsson IM, Tarkowski A, Endogenously oxidized mitochondrial DNA induces in vivo and in vitro inflammatory responses, J Leukoc Biol 75 (2004) 995-1000.

[38] Saxena G, Chen J, Shalev A, Intracellular shuttling and mitochondrial function of thioredoxininteracting protein, J Biol Chem 285 (2010) 3997-4005.

[39] Yoshihara E, Chen Z, Matsuo Y, Masutani H, Yodoi J, Thiol redox transitions by thioredoxin and thioredoxin-binding protein-2 in cell signaling, Methods Enzymol 474 (2010) 67-82.

[40] Lane T, Flam B, Lockey R, Kolliputi N, TXNIP shuttling: missing link between oxidative stress and inflammasome activation, Front Physiol 4 (2013) 50.

[41] Nakahira K, Haspel JA, Rathinam VA, Lee SJ, Dolinay T, Lam HC, Englert JA, Rabinovitch M, Cernadas M, Kim HP, Fitzgerald KA, Ryter SW, Choi AM, Autophagy proteins regulate innate immune responses by inhibiting the release of mitochondrial DNA mediated by the NALP3 inflammasome, Nat Immunol 12 (2011) 222-230. 
[42] Schroder K, Zhou R, Tschopp J, The NLRP3 inflammasome: a sensor for metabolic danger?, Science 327 (2010) 296-300.

[43] Hiramoto K, Kobayashi H, Yamate $\mathrm{Y}$, Ishii M, Sato EF, Intercellular pathway through hyaluronic acid in UVB-induced inflammation, Exp Dermatol 21 (2012) 911-914.

[44] Dostert C, Petrilli V, Van Bruggen R, Steele C, Mossman BT, Tschopp J, Innate immune activation through Nalp3 inflammasome sensing of asbestos and silica, Science 320 (2008) 674-677.

[45] Halle A, Hornung V, Petzold GC, Stewart CR, Monks BG, Reinheckel T, Fitzgerald KA, Latz E, Moore KJ, Golenbock DT, The NALP3 inflammasome is involved in the innate immune response to amyloid-beta, Nat Immunol 9 (2008) 857-865.

[46] Mariathasan S, Weiss DS, Newton K, McBride J, O'Rourke K, Roose-Girma M, Lee WP, Weinrauch Y, Monack DM, Dixit VM, Cryopyrin activates the inflammasome in response to toxins and ATP, Nature 440 (2006) 228-232.

[47] Shimada K, Crother TR, Karlin J, Dagvadorj J, Chiba N, Chen S, Ramanujan VK, Wolf AJ, Vergnes L, Ojcius DM, Rentsendorj A, Vargas M, Guerrero C, Wang Y, Fitzgerald KA, Underhill DM, Town $\mathrm{T}$, Arditi $\mathrm{M}$, Oxidized mitochondrial DNA activates the NLRP3 inflammasome during apoptosis, Immunity 36 (2012) 401-414.

[48] Kanneganti TD, Body-Malapel M, Amer A, Park JH, Whitfield J, Franchi L, Taraporewala ZF, Miller D, Patton JT, Inohara N, Nunez G, Critical role for Cryopyrin/Nalp3 in activation of caspase-1 in response to viral infection and double-stranded RNA, J Biol Chem 281 (2006) 36560-36568.

[49] Takeda K, Akira S, Toll-like receptors in innate immunity, Int Immunol 17 (2005) 1-14. 
[50] Zhang JZ, Liu Z, Liu J, Ren JX, Sun TS, Mitochondrial DNA induces inflammation and increases TLR9/NF-kappaB expression in lung tissue, Int J Mol Med 33 (2014) 817-824.

[51] Wu J, Chen ZJ, Innate immune sensing and signaling of cytosolic nucleic acids, Annu Rev Immunol 32 (2014) 461-488.

[52] Krieg AM, CpG motifs in bacterial DNA and their immune effects, Annu Rev Immunol 20 (2002) 709-760.

[53] Huang H, Evankovich J, Yan W, Nace G, Zhang L, Ross M, Liao X, Billiar T, Xu J, Esmon CT, Tsung A, Endogenous histones function as alarmins in sterile inflammatory liver injury through Tolllike receptor 9 in mice, Hepatology 54 (2011) 999-1008.

[54] Latz E, Schoenemeyer A, Visintin A, Fitzgerald KA, Monks BG, Knetter CF, Lien E, Nilsen NJ, Espevik T, Golenbock DT, TLR9 signals after translocating from the ER to CpG DNA in the Iysosome, Nat Immunol 5 (2004) 190-198.

[55] Takeda K, Kaisho T, Akira S, Toll-like receptors, Annu Rev Immunol 21 (2003) 335-376.

[56] Ding Z, Liu S, Wang X, Khaidakov M, Dai Y, Mehta JL, Oxidant stress in mitochondrial DNA damage, autophagy and inflammation in atherosclerosis, Sci Rep 3 (2013) 1077.

[57] Rathinam VA, Jiang Z, Waggoner SN, Sharma S, Cole LE, Waggoner L, Vanaja SK, Monks BG, Ganesan S, Latz E, Hornung V, Vogel SN, Szomolanyi-Tsuda E, Fitzgerald KA, The AIM2 inflammasome is essential for host defense against cytosolic bacteria and DNA viruses, Nat Immunol 11 (2010) 395-402.

[58] Gehrke N, Mertens C, Zillinger T, Wenzel J, Bald T, Zahn S, Tuting T, Hartmann G, Barchet W, Oxidative damage of DNA confers resistance to cytosolic nuclease TREX1 degradation and potentiates STING-dependent immune sensing, Immunity 39 (2013) 482-495.

[59] Kuechle MK, Elkon KB, Shining light on lupus and UV, Arthritis Res Ther 9 (2007) 101. 
[60] Ishikawa H, Ma Z, Barber GN, STING regulates intracellular DNA-mediated, type I interferondependent innate immunity, Nature 461 (2009) 788-792.

[61] Saitoh T, Fujita N, Hayashi T, Takahara K, Satoh T, Lee H, Matsunaga K, Kageyama S, Omori H, Noda T, Yamamoto N, Kawai T, Ishii K, Takeuchi O, Yoshimori T, Akira S, Atg9a controls dsDNAdriven dynamic translocation of STING and the innate immune response, Proc Natl Acad Sci U S A 106 (2009) 20842-20846.

[62] Abe T, Harashima A, Xia T, Konno H, Konno K, Morales A, Ahn J, Gutman D, Barber GN, STING recognition of cytoplasmic DNA instigates cellular defense, Mol Cell 50 (2013) 5-15.

[63] Unterholzner L, Keating SE, Baran M, Horan KA, Jensen SB, Sharma S, Sirois CM, Jin T, Latz E, Xiao TS, Fitzgerald KA, Paludan SR, Bowie AG, IFI16 is an innate immune sensor for intracellular DNA, Nat Immunol 11 (2010) 997-1004.

[64] Zhang Z, Yuan B, Bao M, Lu N, Kim T, Liu YJ, The helicase DDX41 senses intracellular DNA mediated by the adaptor STING in dendritic cells, Nat Immunol 12 (2011) 959-965.

[65] Sun L, Wu J, Du F, Chen X, Chen ZJ, Cyclic GMP-AMP synthase is a cytosolic DNA sensor that activates the type I interferon pathway, Science 339 (2013) 786-791.

[66] Huang YH, Liu XY, Du XX, Jiang ZF, Su XD, The structural basis for the sensing and binding of cyclic di-GMP by STING, Nat Struct Mol Biol 19 (2012) 728-730.

[67] Parvatiyar K, Zhang Z, Teles RM, Ouyang S, Jiang Y, Iyer SS, Zaver SA, Schenk M, Zeng S, Zhong W, Liu ZJ, Modlin RL, Liu YJ, Cheng G, The helicase DDX41 recognizes the bacterial secondary messengers cyclic di-GMP and cyclic di-AMP to activate a type I interferon immune response, Nat Immunol 13 (2012) 1155-1161.

[68] You Z, Shi LZ, Zhu Q, Wu P, Zhang YW, Basilio A, Tonnu N, Verma IM, Berns MW, Hunter T, CtIP links DNA double-strand break sensing to resection, Mol Cell 36 (2009) 954-969. 
[69] Kondo T, Kobayashi J, Saitoh T, Maruyama K, Ishii KJ, Barber GN, Komatsu K, Akira S, Kawai T, DNA damage sensor MRE11 recognizes cytosolic double-stranded DNA and induces type I interferon by regulating STING trafficking, Proc Natl Acad Sci U S A 110 (2013) 2969-2974.

[70] Yan HX, Wu HP, Zhang HL, Ashton C, Tong C, Wu J, Qian QJ, Wang HY, Ying QL, DNA damageinduced sustained p53 activation contributes to inflammation-associated hepatocarcinogenesis in rats, Oncogene 32 (2013) 4565-4571.

[71] Volcic M, Karl S, Baumann B, Salles D, Daniel P, Fulda S, Wiesmuller L, NF-kappaB regulates DNA double-strand break repair in conjunction with BRCA1-CtIP complexes, Nucleic Acids Res 40 (2012) 181-195.

[72] Swindall AF, Stanley JA, Yang ES, PARP-1: Friend or Foe of DNA Damage and Repair in Tumorigenesis?, Cancers (Basel) 5 (2013) 943-958.

[73] Ivana SA, Diederich M, Modulation of poly(ADP-ribosylation) in apoptotic cells, Biochem Pharmacol 68 (2004) 1041-1047.

[74] David KK, Andrabi SA, Dawson TM, Dawson VL, Parthanatos, a messenger of death, Front Biosci (Landmark Ed) 14 (2009) 1116-1128.

[75] Munoz-Gamez JA, Rodriguez-Vargas JM, Quiles-Perez R, Aguilar-Quesada R, Martin-Oliva D, de Murcia G, Menissier dM, Almendros A, Ruiz dA, Oliver FJ, PARP-1 is involved in autophagy induced by DNA damage, Autophagy 5 (2009) 61-74.

[76] Berger NA, Berger SJ, Metabolic consequences of DNA damage: the role of poly (ADP-ribose) polymerase as mediator of the suicide response, Basic Life Sci 38 (1986) 357-363.

[77] Pacher P, Szabo C, Role of the peroxynitrite-poly(ADP-ribose) polymerase pathway in human disease, Am J Pathol 173 (2008) 2-13. 
[78] Ba X, Garg NJ, Signaling mechanism of poly(ADP-ribose) polymerase-1 (PARP-1) in inflammatory diseases, Am J Pathol 178 (2011) 946-955.

[79] Zhang X, Brann TW, Zhou M, Yang J, Oguariri RM, Lidie KB, Imamichi H, Huang DW, Lempicki RA, Baseler MW, Veenstra TD, Young HA, Lane HC, Imamichi T, Cutting edge: Ku70 is a novel cytosolic DNA sensor that induces type III rather than type I IFN, J Immunol 186 (2011) 45414545 .

[80] Yotsumoto S, Saegusa K, Aramaki Y, Endosomal translocation of CpG-oligodeoxynucleotides inhibits DNA-PKcs-dependent IL-10 production in macrophages, J Immunol 180 (2008) 809816.

[81] Wilson HL, Dar A, Napper SK, Marianela LA, Babiuk LA, Mutwiri GK, Immune mechanisms and therapeutic potential of CpG oligodeoxynucleotides, Int Rev Immunol 25 (2006) 183-213.

[82] Ferguson BJ, Mansur DS, Peters NE, Ren H, Smith GL, DNA-PK is a DNA sensor for IRF-3dependent innate immunity, Elife 1 (2012) e00047.

[83] Lange SS, Vasquez KM, HMGB1: the jack-of-all-trades protein is a master DNA repair mechanic, Mol Carcinog 48 (2009) 571-580.

[84] Pasheva EA, Pashev IG, Favre A, Preferential binding of high mobility group 1 protein to UVdamaged DNA. Role of the COOH-terminal domain, J Biol Chem 273 (1998) 24730-24736.

[85] Ivanov S, Dragoi AM, Wang X, Dallacosta C, Louten J, Musco G, Sitia G, Yap GS, Wan Y, Biron CA, Bianchi ME, Wang H, Chu WM, A novel role for HMGB1 in TLR9-mediated inflammatory responses to CpG-DNA, Blood 110 (2007) 1970-1981.

[86] Tang D, Lotze MT, Tumor immunity times out: TIM-3 and HMGB1, Nat Immunol 13 (2012) 808810. 
[87] Tang D, Shi $Y$, Kang R, Li T, Xiao W, Wang H, Xiao X, Hydrogen peroxide stimulates macrophages and monocytes to actively release HMGB1, J Leukoc Biol 81 (2007) 741-747.

[88] Scaffidi P, Misteli T, Bianchi ME, Release of chromatin protein HMGB1 by necrotic cells triggers inflammation, Nature 418 (2002) 191-195.

[89] Venereau E, Schiraldi M, Uguccioni M, Bianchi ME, HMGB1 and leukocyte migration during trauma and sterile inflammation, Mol Immunol 55 (2013) 76-82.

[90] Yang H, Tracey KJ, Targeting HMGB1 in inflammation, Biochim Biophys Acta 1799 (2010) 149156.

[91] Huttunen HJ, Fages C, Rauvala H, Receptor for advanced glycation end products (RAGE)mediated neurite outgrowth and activation of NF-kappaB require the cytoplasmic domain of the receptor but different downstream signaling pathways, J Biol Chem 274 (1999) 1991919924.

[92] Taguchi A, Blood DC, del Toro G, Canet A, Lee DC, Qu W, Tanji N, Lu Y, Lalla E, Fu C, Hofmann MA, Kislinger T, Ingram M, Lu A, Tanaka H, Hori O, Ogawa S, Stern DM, Schmidt AM, Blockade of RAGE-amphoterin signalling suppresses tumour growth and metastases, Nature 405 (2000) 354-360.

[93] Tadie JM, Bae HB, Jiang S, Park DW, Bell CP, Yang H, Pittet JF, Tracey K, Thannickal VJ, Abraham E, Zmijewski JW, HMGB1 promotes neutrophil extracellular trap formation through interactions with Toll-like receptor 4, Am J Physiol Lung Cell Mol Physiol 304 (2013) L342-L349.

[94] Andersson U, Tracey KJ, HMGB1 is a therapeutic target for sterile inflammation and infection, Annu Rev Immunol 29 (2011) 139-162.

[95] Huang W, Tang Y, Li L, HMGB1, a potent proinflammatory cytokine in sepsis, Cytokine 51 (2010) 119-126. 
[96] Andersson U, Harris HE, The role of HMGB1 in the pathogenesis of rheumatic disease, Biochim Biophys Acta 1799 (2010) 141-148.

[97] Urbonaviciute V, Voll RE, High-mobility group box 1 represents a potential marker of disease activity and novel therapeutic target in systemic lupus erythematosus, J Intern Med 270 (2011) 309-318.

[98] Kang R, Zhang Q, Zeh HJ, III, Lotze MT, Tang D, HMGB1 in cancer: good, bad, or both?, Clin Cancer Res 19 (2013) 4046-4057.

[99] Jia L, Clear A, Liu FT, Matthews J, Uddin N, McCarthy A, Hoxha E, Durance C, Iqbal S, Gribben JG, Extracellular HMGB1 promotes differentiation of nurse-like cells in chronic lymphocytic leukemia, Blood 123 (2014) 1709-1719. 


\section{Supplementary on-line references}

[1] Cadet J, Douki T, Ravanat JL, Oxidatively generated base damage to cellular DNA, Free Radic Biol Med 49 (2010) 9-21.

[2] Altieri F, Grillo C, Maceroni M, Chichiarelli S, DNA damage and repair: from molecular mechanisms to health implications, Antioxid Redox Signal 10 (2008) 891-937.

[3] Whitton PS, Inflammation as a causative factor in the aetiology of Parkinson's disease, $\mathrm{Br} \mathrm{J}$ Pharmacol 150 (2007) 963-976.

[4] Ferrari CC, Tarelli R, Parkinson's disease and systemic inflammation, Parkinsons Dis 2011 (2011) 436813.

[5] van Greevenbroek MM, Schalkwijk CG, Stehouwer CD, Obesity-associated low-grade inflammation in type 2 diabetes mellitus: causes and consequences, Neth J Med 71 (2013) 174-187.

[6] Ohl K, Tenbrock K, Inflammatory cytokines in systemic lupus erythematosus, J Biomed Biotechnol 2011 (2011) 432595.

[7] Hanauer SB, Inflammatory bowel disease: epidemiology, pathogenesis, and therapeutic opportunities, Inflamm Bowel Dis 12 Suppl 1 (2006) S3-S9.

[8] Bianchi ME, DAMPs, PAMPs and alarmins: all we need to know about danger, J Leukoc Biol $81(2007) 1-5$.

[9] Serhan CN, Savill J, Resolution of inflammation: the beginning programs the end, Nat Immunol 6 (2005) 1191-1197.

[10] Nathan C, Neutrophils and immunity: challenges and opportunities, Nat Rev Immunol 6 (2006) 173-182.

[11] Babior BM, The respiratory burst of phagocytes, J Clin Invest 73 (1984) 599-601.

[12] Yang Y, Bazhin AV, Werner J, Karakhanova S, Reactive oxygen species in the immune system, Int Rev Immunol 32 (2013) 249-270.

[13] Nathan C, Cunningham-Bussel A, Beyond oxidative stress: an immunologist's guide to reactive oxygen species, Nat Rev Immunol 13 (2013) 349-361.

[14] Freinbichler W, Colivicchi MA, Stefanini C, Bianchi L, Ballini C, Misini B, Weinberger P, Linert W, Vareslija D, Tipton KF, Della CL, Highly reactive oxygen species: detection, formation, and possible functions, Cell Mol Life Sci 68 (2011) 2067-2079.

[15] Yang CS, Kim JJ, Lee SJ, Hwang JH, Lee CH, Lee MS, Jo EK, TLR3-triggered reactive oxygen species contribute to inflammatory responses by activating signal transducer and activator of transcription-1, J Immunol 190 (2013) 6368-6377. 
[16] Chiang E, Dang O, Anderson K, Matsuzawa A, Ichijo H, David M, Cutting edge: apoptosisregulating signal kinase 1 is required for reactive oxygen species-mediated activation of IFN regulatory factor 3 by lipopolysaccharide, J Immunol 176 (2006) 5720-5724.

[17] Alfonso-Loeches S, Ureña-Peralta JR, Morillo-Bargues MJ, Oliver-De La Cruz J, Guerri C, Role of mitochondria ROS generation in ethanol-induced NLRP3 inflammasome activation and cell death in astroglial cells, Front Cell Neurosci 8 (2014) 1-18.

[18] Zhou R, Tardivel A, Thorens B, Choi I, Tschopp J, Thioredoxin-interacting protein links oxidative stress to inflammasome activation, Nat Immunol 11 (2010) 136-140.

[19] Zhou R, Yazdi AS, Menu P, Tschopp J, A role for mitochondria in NLRP3 inflammasome activation, Nature 469 (2011) 221-225.

[20] Tschopp J, Mitochondria: Sovereign of inflammation?, Eur J Immunol 41 (2011) 1196-1202.

[21] Ziech D, Franco R, Pappa A, Panayiotidis MI, Reactive oxygen species (ROS)--induced genetic and epigenetic alterations in human carcinogenesis, Mutat Res 711 (2011) 167-173.

[22] Avery SV, Molecular targets of oxidative stress, Biochem J 434 (2011) 201-210.

[23] Franceschi C, Bonafe M, Valensin S, Olivieri F, De Luca M, Ottaviani E, De Benedictis G, Inflamm-aging. An evolutionary perspective on immunosenescence, Ann N Y Acad Sci 908 (2000) 244-254.

[24] Licastro F, Grimaldi LM, Bonafe M, Martina C, Olivieri F, Cavallone L, Giovanietti S, Masliah E, Franceschi $C$, Interleukin- 6 gene alleles affect the risk of Alzheimer's disease and levels of the cytokine in blood and brain, Neurobiol Aging 24 (2003) 921-926.

[25] De Martinis M, Franceschi C, Monti D, Ginaldi L, Inflamm-ageing and lifelong antigenic load as major determinants of ageing rate and longevity, FEBS Lett 579 (2005) 2035-2039.

[26] De Martinis M, Franceschi C, Monti D, Ginaldi L, Inflammation markers predicting frailty and mortality in the elderly, Exp Mol Pathol 80 (2006) 219-227.

[27] Reddy VP, Zhu X, Perry G, Smith MA, Oxidative stress in diabetes and Alzheimer's disease, J Alzheimers Dis 16 (2009) 763-774.

[28] Krishnan KJ, Reeve AK, Turnbull DM, Do mitochondrial DNA mutations have a role in neurodegenerative disease?, Biochem Soc Trans 35 (2007) 1232-1235.

[29] Newsholme P, Haber EP, Hirabara SM, Rebelato EL, Procopio J, Morgan D, Oliveira-Emilio HC, Carpinelli AR, Curi R, Diabetes associated cell stress and dysfunction: role of mitochondrial and non-mitochondrial ROS production and activity, J Physiol 583 (2007) 9-24.

[30] Muller WE, Eckert A, Kurz C, Eckert GP, Leuner K, Mitochondrial dysfunction: common final pathway in brain aging and Alzheimer's disease--therapeutic aspects, Mol Neurobiol 41 (2010) 159-171.

[31] Valko M, Leibfritz D, Moncol J, Cronin MT, Mazur M, Telser J, Free radicals and antioxidants in normal physiological functions and human disease, Int J Biochem Cell Biol 39 (2007) 44-84. 
[32] Ferguson LR, Role of dietary mutagens in cancer and atherosclerosis, Curr Opin Clin Nutr Metab Care 12 (2009) 343-349.

[33] Chatterjee A, Mambo E, Sidransky D, Mitochondrial DNA mutations in human cancer, Oncogene 25 (2006) 4663-4674.

[34] Hussain SP, Hofseth LJ, Harris CC, Radical causes of cancer, Nat Rev Cancer 3 (2003) 276-285.

[35] O'Neill P, Wardman P, Radiation chemistry comes before radiation biology, Int J Radiat Biol 85 (2009) 9-25.

[36] McMillan TJ, Leatherman E, Ridley A, Shorrocks J, Tobi SE, Whiteside JR, Cellular effects of long wavelength UV light (UVA) in mammalian cells, J Pharm Pharmacol 60 (2008) 969-976.

[37] Cooke MS, Evans MD, Dizdaroglu M, Lunec J, Oxidative DNA damage: mechanisms, mutation, and disease, FASEB J 17 (2003) 1195-1214.

[38] Evans MD, Dizdaroglu M, Cooke MS, Oxidative DNA damage and disease: induction, repair and significance, Mutat Res 567 (2004) 1-61.

[39] Ott M, Gogvadze V, Orrenius S, Zhivotovsky B, Mitochondria, oxidative stress and cell death, Apoptosis 12 (2007) 913-922.

[40] Naik E, Dixit VM, Mitochondrial reactive oxygen species drive proinflammatory cytokine production, J Exp Med 208 (2011) 417-420.

[41] Lam GY, Huang J, Brumell JH, The many roles of NOX2 NADPH oxidase-derived ROS in immunity, Semin Immunopathol 32 (2010) 415-430.

[42] McCord JM, Fridovich I, Superoxide dismutase. An enzymic function for erythrocuprein (hemocuprein), J Biol Chem 244 (1969) 6049-6055.

[43] Babior BM, Kipnes RS, Curnutte JT, Biological defense mechanisms. The production by leukocytes of superoxide, a potential bactericidal agent, J Clin Invest 52 (1973) 741-744.

[44] Miller EW, Dickinson BC, Chang CJ, Aquaporin-3 mediates hydrogen peroxide uptake to regulate downstream intracellular signaling, Proc Natl Acad Sci U S A 107 (2010) 1568115686.

[45] Wu W, Chen Y, Hazen SL, Eosinophil peroxidase nitrates protein tyrosyl residues. Implications for oxidative damage by nitrating intermediates in eosinophilic inflammatory disorders, J Biol Chem 274 (1999) 25933-25944.

[46] Eiserich JP, Hristova M, Cross CE, Jones AD, Freeman BA, Halliwell B, van d, V, Formation of nitric oxide-derived inflammatory oxidants by myeloperoxidase in neutrophils, Nature 391 (1998) 393-397.

[47] Gungor N, Haegens A, Knaapen AM, Godschalk RW, Chiu RK, Wouters EF, Van Schooten FJ, Lung inflammation is associated with reduced pulmonary nucleotide excision repair in vivo, Mutagenesis 25 (2010) 77-82. 
[48] Dizdaroglu M, Rao G, Halliwell B, Gajewski E, Damage to the DNA bases in mammalian chromatin by hydrogen peroxide in the presence of ferric and cupric ions, Arch Biochem Biophys 285 (1991) 317-324.

[49] Aruoma OI, Halliwell B, Gajewski E, Dizdaroglu M, Copper-ion-dependent damage to the bases in DNA in the presence of hydrogen peroxide, Biochem J 273 ( Pt 3) (1991) 601-604.

[50] Lopez LC, Escames G, Tapias V, Utrilla P, Leon J, Acuna-Castroviejo D, Identification of an inducible nitric oxide synthase in diaphragm mitochondria from septic mice: its relation with mitochondrial dysfunction and prevention by melatonin, Int J Biochem Cell Biol 38 (2006) 267-278.

[51] Lonkar P, Dedon PC, Reactive species and DNA damage in chronic inflammation: reconciling chemical mechanisms and biological fates, Int J Cancer 128 (2011) 1999-2009.

[52] Hughes MN, Chemistry of nitric oxide and related species, Methods Enzymol 436 (2008) 319.

[53] Thomas DD, Ridnour LA, Isenberg JS, Flores-Santana W, Switzer CH, Donzelli S, Hussain $P$, Vecoli C, Paolocci N, Ambs S, Colton CA, Harris CC, Roberts DD, Wink DA, The chemical biology of nitric oxide: implications in cellular signaling, Free Radic Biol Med 45 (2008) 18-31.

[54] Bae YS, Oh H, Rhee SG, Yoo YD, Regulation of reactive oxygen species generation in cell signaling, Mol Cells 32 (2011) 491-509.

[55] Holmgren A, Lu J, Thioredoxin and thioredoxin reductase: current research with special reference to human disease, Biochem Biophys Res Commun 396 (2010) 120-124.

[56] Weissbach H, Etienne F, Hoshi T, Heinemann SH, Lowther WT, Matthews B, St John G, Nathan C, Brot N, Peptide methionine sulfoxide reductase: structure, mechanism of action, and biological function, Arch Biochem Biophys 397 (2002) 172-178.

[57] Bryk R, Griffin P, Nathan C, Peroxynitrite reductase activity of bacterial peroxiredoxins, Nature 407 (2000) 211-215.

[58] Anastasiou D, Poulogiannis G, Asara JM, Boxer MB, Jiang JK, Shen M, Bellinger G, Sasaki AT, Locasale JW, Auld DS, Thomas CJ, Vander Heiden MG, Cantley LC, Inhibition of pyruvate kinase $M 2$ by reactive oxygen species contributes to cellular antioxidant responses, Science 334 (2011) 1278-1283.

[59] O'Donnell-Tormey J, Nathan CF, Lanks K, DeBoer CJ, de la HJ, Secretion of pyruvate. An antioxidant defense of mammalian cells, J Exp Med 165 (1987) 500-514.

[60] Cadet J, Ravanat JL, TavernaPorro M, Menoni H, Angelov D, Oxidatively generated complex DNA damage: tandem and clustered lesions, Cancer Lett 327 (2012) 5-15.

[61] Jena NR, DNA damage by reactive species: Mechanisms, mutation and repair, J Biosci 37 (2012) 503-517.

[62] Grisham MB, Jourd'heuil D, Wink DA, Review article: chronic inflammation and reactive oxygen and nitrogen metabolism--implications in DNA damage and mutagenesis, Aliment Pharmacol Ther 14 Suppl 1 (2000) 3-9. 
[63] Eiberger W, Volkmer B, Amouroux R, Dherin C, Radicella JP, Epe B, Oxidative stress impairs the repair of oxidative DNA base modifications in human skin fibroblasts and melanoma cells, DNA Repair (Amst) 7 (2008) 912-921.

[64] Sanchez M, Torres JV, Tormos C, Iradi A, Muniz P, Espinosa O, Salvador A, Rodriguez-Delgado J, Fandos M, Saez GT, Impairment of antioxidant enzymes, lipid peroxidation and 8-oxo-2'deoxyguanosine in advanced epithelial ovarian carcinoma of a Spanish community, Cancer Lett 233 (2006) 28-35.

[65] Malins DC, Johnson PM, Barker EA, Polissar NL, Wheeler TM, Anderson KM, Cancer-related changes in prostate DNA as men age and early identification of metastasis in primary prostate tumors, Proc Natl Acad Sci U S A 100 (2003) 5401-5406.

[66] Wilson DM, III, Sofinowski TM, McNeill DR, Repair mechanisms for oxidative DNA damage, Front Biosci 8 (2003) d963-d981.

[67] Slupphaug G, Kavli B, Krokan HE, The interacting pathways for prevention and repair of oxidative DNA damage, Mutat Res 531 (2003) 231-251.

[68] Zharkov DO, Base excision DNA repair, Cell Mol Life Sci 65 (2008) 1544-1565.

[69] Deans AJ, West SC, DNA interstrand crosslink repair and cancer, Nat Rev Cancer 11 (2011) 467-480.

[70] Lieber MR, The mechanism of double-strand DNA break repair by the nonhomologous DNA end-joining pathway, Annu Rev Biochem 79 (2010) 181-211.

[71] Lamarche BJ, Orazio NI, Weitzman MD, The MRN complex in double-strand break repair and telomere maintenance, FEBS Lett 584 (2010) 3682-3695.

[72] Groth P, Orta ML, Elvers I, Majumder MM, Lagerqvist A, Helleday T, Homologous recombination repairs secondary replication induced DNA double-strand breaks after ionizing radiation, Nucleic Acids Res 40 (2012) 6585-6594.

[73] Asahi T, Kondo H, Masuda M, Nishino H, Aratani Y, Naito Y, Yoshikawa T, Hisaka S, Kato Y, Osawa T, Chemical and immunochemical detection of 8-halogenated deoxyguanosines at early stage inflammation, J Biol Chem 285 (2010) 9282-9291.

[74] Dedon PC, Tannenbaum SR, Reactive nitrogen species in the chemical biology of inflammation, Arch Biochem Biophys 423 (2004) 12-22.

[75] Hiraku Y, Sakai K, Shibata E, Kamijima M, Hisanaga N, Ma N, Kawanishi S, Murata M, Formation of the Nitrative DNA Lesion 8-nitroguanine is Associated with Asbestos Contents in Human Lung Tissues: A Pilot Atudy, J Occup Health(2014)

[76] Hiraku $Y$, Kawanishi S, Ichinose T, Murata M, The role of iNOS-mediated DNA damage in infection- and asbestos-induced carcinogenesis, Ann N Y Acad Sci 1203 (2010) 15-22.

[77] Niles JC, Wishnok JS, Tannenbaum SR, Peroxynitrite-induced oxidation and nitration products of guanine and 8-oxoguanine: structures and mechanisms of product formation, Nitric Oxide 14 (2006) 109-121. 
[78] Kawanishi S, Hiraku Y, Oxidative and nitrative DNA damage as biomarker for carcinogenesis with special reference to inflammation, Antioxid Redox Signal 8 (2006) 1047-1058.

[79] Kawanishi S, Hiraku Y, Pinlaor S, Ma N, Oxidative and nitrative DNA damage in animals and patients with inflammatory diseases in relation to inflammation-related carcinogenesis, Biol Chem 387 (2006) 365-372.

[80] Dizdaroglu M, Jaruga P, Mechanisms of free radical-induced damage to DNA, Free Radic Res 46 (2012) 382-419.

[81] Steenken S, Jovanovic SV, How Easily Oxidizable Is DNA? One-Electron Reduction Potentials of Adenosine and Guanosine Radicals in Aqueous Solution, J Am Chem Soc 119 (1997) 617618.

[82] Dedon PC, The chemical toxicology of 2-deoxyribose oxidation in DNA, Chem Res Toxicol 21 (2008) 206-219.

[83] Jena NR, Mishra PC, Formation of ring-opened and rearranged products of guanine: mechanisms and biological significance, Free Radic Biol Med 53 (2012) 81-94.

[84] Dechakhamphu S, Pinlaor S, Sitthithaworn P, Nair J, Bartsch H, Yongvanit P, Lipid peroxidation and etheno DNA adducts in white blood cells of liver fluke-infected patients: protection by plasma alpha-tocopherol and praziquantel, Cancer Epidemiol Biomarkers Prev 19 (2010) 310-318.

[85] Nair U, Bartsch H, Nair J, Lipid peroxidation-induced DNA damage in cancer-prone inflammatory diseases: a review of published adduct types and levels in humans, Free Radic Biol Med 43 (2007) 1109-1120.

[86] Hong $\mathrm{H}$, Cao $\mathrm{H}$, Wang $\mathrm{Y}$, Formation and genotoxicity of a guanine-cytosine intrastrand crosslink lesion in vivo, Nucleic Acids Res 35 (2007) 7118-7127.

[87] Wang Y, Bulky DNA lesions induced by reactive oxygen species, Chem Res Toxicol 21 (2008) 276-281.

[88] Malyarchuk S, Castore R, Harrison L, DNA repair of clustered lesions in mammalian cells: involvement of non-homologous end-joining, Nucleic Acids Res 36 (2008) 4872-4882.

[89] Harper JV, Anderson JA, O'Neill P, Radiation induced DNA DSBs: Contribution from stalled replication forks?, DNA Repair (Amst) 9 (2010) 907-913.

[90] Druzhyna NM, Wilson GL, LeDoux SP, Mitochondrial DNA repair in aging and disease, Mech Ageing Dev 129 (2008) 383-390.

[91] Kazak L, Reyes A, Holt IJ, Minimizing the damage: repair pathways keep mitochondrial DNA intact, Nat Rev Mol Cell Biol 13 (2012) 659-671.

[92] Alexeyev M, Shokolenko I, Wilson G, LeDoux S, The maintenance of mitochondrial DNA integrity--critical analysis and update, Cold Spring Harb Perspect Biol 5 (2013) a012641.

[93] Alexeyev MF, Is there more to aging than mitochondrial DNA and reactive oxygen species?, FEBS J 276 (2009) 5768-5787. 
[94] Halliwell B, Aruoma OI, DNA damage by oxygen-derived species. Its mechanism and measurement in mammalian systems, FEBS Lett 281 (1991) 9-19.

[95] De Bont R, Van Larebeke N, Endogenous DNA damage in humans: a review of quantitative data, Mutagenesis 19 (2004) 169-185.

[96] Bohr VA, Repair of oxidative DNA damage in nuclear and mitochondrial DNA, and some changes with aging in mammalian cells, Free Radic Biol Med 32 (2002) 804-812.

[97] Wang D, Kreutzer DA, Essigmann JM, Mutagenicity and repair of oxidative DNA damage: insights from studies using defined lesions, Mutat Res 400 (1998) 99-115.

[98] Boesch P, Weber-Lotfi F, Ibrahim N, Tarasenko V, Cosset A, Paulus F, Lightowlers RN, Dietrich $A$, DNA repair in organelles: Pathways, organization, regulation, relevance in disease and aging, Biochim Biophys Acta 1813 (2011) 186-200.

[99] El Khamisy SF, Caldecott KW, DNA single-strand break repair and spinocerebellar ataxia with axonal neuropathy-1, Neuroscience 145 (2007) 1260-1266.

[100] Kasparek TR, Humphrey TC, DNA double-strand break repair pathways, chromosomal rearrangements and cancer, Semin Cell Dev Biol 22 (2011) 886-897.

[101] Svilar D, Goellner EM, Almeida KH, Sobol RW, Base excision repair and lesion-dependent subpathways for repair of oxidative DNA damage, Antioxid Redox Signal 14 (2011) 24912507.

[102] Hegde ML, Izumi T, Mitra S, Oxidized base damage and single-strand break repair in mammalian genomes: role of disordered regions and posttranslational modifications in early enzymes, Prog Mol Biol Transl Sci 110 (2012) 123-153.

[103] D'Aurelio M, Gajewski CD, Lin MT, Mauck WM, Shao LZ, Lenaz G, Moraes CT, Manfredi G, Heterologous mitochondrial DNA recombination in human cells, Hum Mol Genet 13 (2004) 3171-3179.

[104] Bacman SR, Williams SL, Moraes CT, Intra- and inter-molecular recombination of mitochondrial DNA after in vivo induction of multiple double-strand breaks, Nucleic Acids Res 37 (2009) 4218-4226.

[105] Shokolenko I, Venediktova N, Bochkareva A, Wilson GL, Alexeyev MF, Oxidative stress induces degradation of mitochondrial DNA, Nucleic Acids Res 37 (2009) 2539-2548.

[106] Kukat A, Kukat C, Brocher J, Schafer I, Krohne G, Trounce IA, Villani G, Seibel P, Generation of rho 0 cells utilizing a mitochondrially targeted restriction endonuclease and comparative analyses, Nucleic Acids Res 36 (2008) e44.

[107] Mansouri A, Demeilliers C, Amsellem S, Pessayre D, Fromenty B, Acute ethanol administration oxidatively damages and depletes mitochondrial dna in mouse liver, brain, heart, and skeletal muscles: protective effects of antioxidants, J Pharmacol Exp Ther 298 (2001) 737-743.

[108] Mitsuishi M, Miyashita K, Muraki A, Itoh H, Angiotensin II reduces mitochondrial content in skeletal muscle and affects glycemic control, Diabetes 58 (2009) 710-717. 
[109] Suliman HB, Carraway MS, Piantadosi CA, Postlipopolysaccharide oxidative damage of mitochondrial DNA, Am J Respir Crit Care Med 167 (2003) 570-579.

[110] Escames G, Lopez LC, Garcia JA, Garcia-Corzo L, Ortiz F, Acuna-Castroviejo D, Mitochondrial DNA and inflammatory diseases, Hum Genet 131 (2012) 161-173.

[111] Jaiswal M, LaRusso NF, Nishioka N, Nakabeppu Y, Gores GJ, Human Ogg1, a protein involved in the repair of 8-oxoguanine, is inhibited by nitric oxide, Cancer Res 61 (2001) 6388-6393.

[112] Kidane D, Chae WJ, Czochor J, Eckert KA, Glazer PM, Bothwell AL, Sweasy JB, Interplay between DNA repair and inflammation, and the link to cancer, Crit Rev Biochem Mol Biol 49 (2014) 116-139.

[113] Nowsheen S, Wukovich RL, Aziz K, Kalogerinis PT, Richardson CC, Panayiotidis MI, Bonner WM, Sedelnikova OA, Georgakilas AG, Accumulation of oxidatively induced clustered DNA lesions in human tumor tissues, Mutat Res 674 (2009) 131-136.

[114] Ermakov AV, Konkova MS, Kostyuk SV, Egolina NA, Efremova LV, Veiko NN, Oxidative stress as a significant factor for development of an adaptive response in irradiated and nonirradiated human lymphocytes after inducing the bystander effect by low-dose Xradiation, Mutat Res 669 (2009) 155-161.

[115] Atamaniuk J, Hsiao YY, Mustak M, Bernhard D, Erlacher L, Fodinger M, Tiran B, Stuhlmeier KM, Analysing cell-free plasma DNA and SLE disease activity, Eur J Clin Invest 41 (2011) 579583.

[116] Breitbach S, Tug S, Simon P, Circulating cell-free DNA: an up-coming molecular marker in exercise physiology, Sports Med 42 (2012) 565-586.

[117] Jylhava J, Nevalainen T, Marttila S, Jylha M, Hervonen A, Hurme M, Characterization of the role of distinct plasma cell-free DNA species in age-associated inflammation and frailty, Aging Cell 12 (2013) 388-397.

[118] Mittra I, Nair NK, Mishra PK, Nucleic acids in circulation: are they harmful to the host?, J Biosci 37 (2012) 301-312.

[119] Adams DH, The problem of cytoplasmic DNA: its extrusion/uptake by cultured cells and its possible role in cell-cell information transfer, Int J Biochem 17 (1985) 1133-1141.

[120] Ermakov AV, Konkova MS, Kostyuk SV, Smirnova TD, Malinovskaya EM, Efremova LV, Veiko NN, An extracellular DNA mediated bystander effect produced from low dose irradiated endothelial cells, Mutat Res 712 (2011) 1-10.

[121] Glebova K, Veiko N, Kostyuk S, Izhevskaya V, Baranova A, Oxidized extracellular DNA as a stress signal that may modify response to anticancer therapy, Cancer Lett(2013)

[122] Prise KM, O'Sullivan JM, Radiation-induced bystander signalling in cancer therapy, Nat Rev Cancer 9 (2009) 351-360.

[123] Butterworth KT, McMahon SJ, Hounsell AR, O'Sullivan JM, Prise KM, Bystander signalling: exploring clinical relevance through new approaches and new models, Clin Oncol (R Coll Radiol ) 25 (2013) 586-592. 
[124] Bergsbaken T, Fink SL, Cookson BT, Pyroptosis: host cell death and inflammation, Nat Rev Microbiol 7 (2009) 99-109.

[125] Miao EA, Rajan JV, Aderem A, Caspase-1-induced pyroptotic cell death, Immunol Rev 243 (2011) 206-214.

[126] Kockritz-Blickwede $M$, Nizet $V$, Innate immunity turned inside-out: antimicrobial defense by phagocyte extracellular traps, J Mol Med (Berl) 87 (2009) 775-783.

[127] Brinkmann V, Reichard U, Goosmann C, Fauler B, Uhlemann Y, Weiss DS, Weinrauch Y, Zychlinsky A, Neutrophil extracellular traps kill bacteria, Science 303 (2004) 1532-1535.

[128] Brinkmann V, Zychlinsky A, Beneficial suicide: why neutrophils die to make NETs, Nat Rev Microbiol 5 (2007) 577-582.

[129] Hauser CJ, Sursal T, Rodriguez EK, Appleton PT, Zhang Q, Itagaki K, Mitochondrial damage associated molecular patterns from femoral reamings activate neutrophils through formyl peptide receptors and P44/42 MAP kinase, J Orthop Trauma 24 (2010) 534-538.

[130] Machado AM, Desler C, Boggild S, Strickertsson JA, Friis-Hansen L, Figueiredo C, Seruca R, Rasmussen $\mathrm{LJ}$, Helicobacter pylori infection affects mitochondrial function and DNA repair, thus, mediating genetic instability in gastric cells, Mech Ageing Dev 134 (2013) 460-466.

[131] Machado AM, Figueiredo C, Touati E, Maximo V, Sousa S, Michel V, Carneiro F, Nielsen FC, Seruca R, Rasmussen $\mathrm{L}$, Helicobacter pylori infection induces genetic instability of nuclear and mitochondrial DNA in gastric cells, Clin Cancer Res 15 (2009) 2995-3002.

[132] Machado AM, Figueiredo C, Seruca R, Rasmussen LJ, Helicobacter pylori infection generates genetic instability in gastric cells, Biochim Biophys Acta 1806 (2010) 58-65.

[133] Demir M, Gokturk HS, Ozturk NA, Kulaksizoglu M, Serin E, Yilmaz U, Helicobacter pylori prevalence in diabetes mellitus patients with dyspeptic symptoms and its relationship to glycemic control and late complications, Dig Dis Sci 53 (2008) 2646-2649.

[134] Hajizadeh S, DeGroot J, TeKoppele JM, Tarkowski A, Collins LV, Extracellular mitochondrial DNA and oxidatively damaged DNA in synovial fluid of patients with rheumatoid arthritis, Arthritis Res Ther 5 (2003) R234-R240.

[135] Zhou J, Chng WJ, Roles of thioredoxin binding protein (TXNIP) in oxidative stress, apoptosis and cancer, Mitochondrion 13 (2013) 163-169.

[136] Shah A, Xia L, Goldberg H, Lee KW, Quaggin SE, Fantus IG, Thioredoxin-interacting protein mediates high glucose-induced reactive oxygen species generation by mitochondria and the NADPH oxidase, Nox4, in mesangial cells, J Biol Chem 288 (2013) 6835-6848.

[137] Yoshioka J, Chutkow WA, Lee S, Kim JB, Yan J, Tian R, Lindsey ML, Feener EP, Seidman CE, Seidman JG, Lee RT, Deletion of thioredoxin-interacting protein in mice impairs mitochondrial function but protects the myocardium from ischemia-reperfusion injury, J Clin Invest 122 (2012) 267-279.

[138] Ashrafi G, Schwarz TL, The pathways of mitophagy for quality control and clearance of mitochondria, Cell Death Differ 20 (2013) 31-42. 
[139] Mcllwain DR, Berger T, Mak TW, Caspase functions in cell death and disease, Cold Spring Harb Perspect Biol 5 (2013) a008656.

[140] Dunne A, Inflammasome activation: from inflammatory disease to infection, Biochem Soc Trans 39 (2011) 669-673.

[141] Bauernfeind F, Bartok E, Rieger A, Franchi L, Nunez G, Hornung V, Cutting edge: reactive oxygen species inhibitors block priming, but not activation, of the NLRP3 inflammasome, J Immunol 187 (2011) 613-617.

[142] Subramanian N, Natarajan K, Clatworthy MR, Wang Z, Germain RN, The adaptor MAVS promotes NLRP3 mitochondrial localization and inflammasome activation, Cell 153 (2013) 348-361.

[143] Latz E, The inflammasomes: mechanisms of activation and function, Curr Opin Immunol 22 (2010) 28-33.

[144] Martinon F, Mayor A, Tschopp J, The inflammasomes: guardians of the body, Annu Rev Immunol 27 (2009) 229-265.

[145] Martinon F, Gaide O, Petrilli V, Mayor A, Tschopp J, NALP inflammasomes: a central role in innate immunity, Semin Immunopathol 29 (2007) 213-229.

[146] Hayden MS, Ghosh S, NF-kappaB, the first quarter-century: remarkable progress and outstanding questions, Genes Dev 26 (2012) 203-234.

[147] Fink SL, Cookson BT, Caspase-1-dependent pore formation during pyroptosis leads to osmotic lysis of infected host macrophages, Cell Microbiol 8 (2006) 1812-1825.

[148] Pugin J, How tissue injury alarms the immune system and causes a systemic inflammatory response syndrome, Ann Intensive Care 2 (2012) 27.

[149] Zhang Q, Itagaki K, Hauser CJ, Mitochondrial DNA is released by shock and activates neutrophils via p38 map kinase, Shock 34 (2010) 55-59.

[150] Falkenberg M, Larsson NG, Gustafsson CM, DNA replication and transcription in mammalian mitochondria, Annu Rev Biochem 76 (2007) 679-699.

[151] Holt IJ, He J, Mao CC, Boyd-Kirkup JD, Martinsson P, Sembongi H, Reyes A, Spelbrink JN, Mammalian mitochondrial nucleoids: organizing an independently minded genome, Mitochondrion 7 (2007) 311-321.

[152] Zgur-Bertok D, DNA damage repair and bacterial pathogens, PLoS Pathog 9 (2013) e1003711.

[153] Kondo T, Kobayashi J, Saitoh T, Maruyama K, Ishii KJ, Barber GN, Komatsu K, Akira S, Kawai T, DNA damage sensor MRE11 recognizes cytosolic double-stranded DNA and induces type I interferon by regulating STING trafficking, Proc Natl Acad Sci U S A 110 (2013) 2969-2974.

[154] Ferguson BJ, Mansur DS, Peters NE, Ren H, Smith GL, DNA-PK is a DNA sensor for IRF-3dependent innate immunity, Elife 1 (2012) e00047. 
[155] Unterholzner L, Keating SE, Baran M, Horan KA, Jensen SB, Sharma S, Sirois CM, Jin T, Latz E, Xiao TS, Fitzgerald KA, Paludan SR, Bowie AG, IFI16 is an innate immune sensor for intracellular DNA, Nat Immunol 11 (2010) 997-1004.

[156] Zhang Z, Yuan B, Bao M, Lu N, Kim T, Liu YJ, The helicase DDX41 senses intracellular DNA mediated by the adaptor STING in dendritic cells, Nat Immunol 12 (2011) 959-965.

[157] Chiu YH, Macmillan JB, Chen ZJ, RNA polymerase III detects cytosolic DNA and induces type I interferons through the RIG-I pathway, Cell 138 (2009) 576-591.

[158] Sun L, Wu J, Du F, Chen X, Chen ZJ, Cyclic GMP-AMP synthase is a cytosolic DNA sensor that activates the type I interferon pathway, Science 339 (2013) 786-791.

[159] Keating SE, Baran M, Bowie AG, Cytosolic DNA sensors regulating type I interferon induction, Trends Immunol 32 (2011) 574-581.

[160] Ishikawa H, Ma Z, Barber GN, STING regulates intracellular DNA-mediated, type I interferondependent innate immunity, Nature 461 (2009) 788-792.

[161] Abe T, Harashima A, Xia T, Konno H, Konno K, Morales A, Ahn J, Gutman D, Barber GN, STING recognition of cytoplasmic DNA instigates cellular defense, Mol Cell 50 (2013) 5-15.

[162] Ahn J, Gutman D, Saijo S, Barber GN, STING manifests self DNA-dependent inflammatory disease, Proc Natl Acad Sci U S A 109 (2012) 19386-19391.

[163] Unterholzner $L$, The interferon response to intracellular DNA: why so many receptors?, Immunobiology 218 (2013) 1312-1321.

[164] Sharma S, DeOliveira RB, Kalantari P, Parroche P, Goutagny N, Jiang Z, Chan J, Bartholomeu DC, Lauw F, Hall JP, Barber GN, Gazzinelli RT, Fitzgerald KA, Golenbock DT, Innate immune recognition of an AT-rich stem-loop DNA motif in the Plasmodium falciparum genome, Immunity 35 (2011) 194-207.

[165] Pisetsky DS, The origin and properties of extracellular DNA: from PAMP to DAMP, Clin Immunol 144 (2012) 32-40.

[166] Yanai H, Ban T, Wang Z, Choi MK, Kawamura T, Negishi H, Nakasato M, Lu Y, Hangai S, Koshiba R, Savitsky D, Ronfani L, Akira S, Bianchi ME, Honda K, Tamura T, Kodama T, Taniguchi T, HMGB proteins function as universal sentinels for nucleic-acid-mediated innate immune responses, Nature 462 (2009) 99-103.

[167] Wang C, Fei G, Liu Z, Li Q, Xu Z, Ren T, HMGB1 was a pivotal synergistic effecor for CpG oligonucleotide to enhance the progression of human lung cancer cells, Cancer Biol Ther 13 (2012) 727-736.

[168] Hornung V, Latz E, Intracellular DNA recognition, Nat Rev Immunol 10 (2010) 123-130.

[169] Schnare M, Holt AC, Takeda K, Akira S, Medzhitov R, Recognition of CpG DNA is mediated by signaling pathways dependent on the adaptor protein MyD88, Curr Biol 10 (2000) 11391142. 
[170] Zhang Q, Raoof M, Chen Y, Sumi Y, Sursal T, Junger W, Brohi K, Itagaki K, Hauser CJ, Circulating mitochondrial DAMPs cause inflammatory responses to injury, Nature 464 (2010) 104-107.

[171] Oka T, Hikoso S, Yamaguchi O, Taneike M, Takeda T, Tamai T, Oyabu J, Murakawa T, Nakayama H, Nishida K, Akira S, Yamamoto A, Komuro I, Otsu K, Mitochondrial DNA that escapes from autophagy causes inflammation and heart failure, Nature 485 (2012) 251-255.

[172] Rovillain E, Mansfield L, Caetano C, Alvarez-Fernandez M, Caballero OL, Medema RH, Hummerich $\mathrm{H}$, Jat PS, Activation of nuclear factor-kappa B signalling promotes cellular senescence, Oncogene 30 (2011) 2356-2366.

[173] Rahman A, Fazal F, Blocking NF-kappaB: an inflammatory issue, Proc Am Thorac Soc 8 (2011) 497-503.

[174] Takeda K, Akira S, TLR signaling pathways, Semin Immunol 16 (2004) 3-9.

[175] O'Neill LA, Golenbock D, Bowie AG, The history of Toll-like receptors - redefining innate immunity, Nat Rev Immunol 13 (2013) 453-460.

[176] Oeckinghaus A, Hayden MS, Ghosh S, Crosstalk in NF-kappaB signaling pathways, Nat Immunol 12 (2011) 695-708.

[177] Shimada K, Crother TR, Karlin J, Dagvadorj J, Chiba N, Chen S, Ramanujan VK, Wolf AJ, Vergnes L, Ojcius DM, Rentsendorj A, Vargas M, Guerrero C, Wang Y, Fitzgerald KA, Underhill DM, Town T, Arditi M, Oxidized mitochondrial DNA activates the NLRP3 inflammasome during apoptosis, Immunity 36 (2012) 401-414.

[178] Nakahira K, Haspel JA, Rathinam VA, Lee SJ, Dolinay T, Lam HC, Englert JA, Rabinovitch M, Cernadas M, Kim HP, Fitzgerald KA, Ryter SW, Choi AM, Autophagy proteins regulate innate immune responses by inhibiting the release of mitochondrial DNA mediated by the NALP3 inflammasome, Nat Immunol 12 (2011) 222-230.

[179] Metzler KD, Fuchs TA, Nauseef WM, Reumaux D, Roesler J, Schulze I, Wahn V, Papayannopoulos V, Zychlinsky A, Myeloperoxidase is required for neutrophil extracellular trap formation: implications for innate immunity, Blood 117 (2011) 953-959.

[180] Ivashkiv LB, Donlin LT, Regulation of type I interferon responses, Nat Rev Immunol 14 (2014) 36-49.

[181] Platanias LC, Mechanisms of type-I- and type-II-interferon-mediated signalling, Nat Rev Immunol 5 (2005) 375-386.

[182] Gao D, Wu J, Wu YT, Du F, Aroh C, Yan N, Sun L, Chen ZJ, Cyclic GMP-AMP synthase is an innate immune sensor of HIV and other retroviruses, Science 341 (2013) 903-906.

[183] Wu J, Sun L, Chen X, Du F, Shi H, Chen C, Chen ZJ, Cyclic GMP-AMP is an endogenous second messenger in innate immune signaling by cytosolic DNA, Science 339 (2013) 826-830.

[184] Woodward JJ, lavarone AT, Portnoy DA, c-di-AMP secreted by intracellular Listeria monocytogenes activates a host type I interferon response, Science 328 (2010) 1703-1705. 
[185] Burdette DL, Monroe KM, Sotelo-Troha K, Iwig JS, Eckert B, Hyodo M, Hayakawa Y, Vance RE, STING is a direct innate immune sensor of cyclic di-GMP, Nature 478 (2011) 515-518.

[186] Choi MK, Wang Z, Ban T, Yanai H, Lu Y, Koshiba R, Nakaima Y, Hangai S, Savitsky D, Nakasato M, Negishi H, Takeuchi O, Honda K, Akira S, Tamura T, Taniguchi T, A selective contribution of the RIG-I-like receptor pathway to type I interferon responses activated by cytosolic DNA, Proc Natl Acad Sci U S A 106 (2009) 17870-17875.

[187] Stetson DB, Medzhitov R, Recognition of cytosolic DNA activates an IRF3-dependent innate immune response, Immunity 24 (2006) 93-103.

[188] Cheng G, Zhong J, Chung J, Chisari FV, Double-stranded DNA and double-stranded RNA induce a common antiviral signaling pathway in human cells, Proc Natl Acad Sci U S A 104 (2007) 9035-9040.

[189] Paull TT, Gellert M, Nbs1 potentiates ATP-driven DNA unwinding and endonuclease cleavage by the Mre11/Rad50 complex, Genes Dev 13 (1999) 1276-1288.

[190] Williams RS, Dodson GE, Limbo O, Yamada Y, Williams JS, Guenther G, Classen S, Glover JN, Iwasaki H, Russell P, Tainer JA, Nbs1 flexibly tethers Ctp1 and Mre11-Rad50 to coordinate DNA double-strand break processing and repair, Cell 139 (2009) 87-99.

[191] Wang H, Shi LZ, Wong CC, Han X, Hwang PY, Truong LN, Zhu Q, Shao Z, Chen DJ, Berns MW, Yates JR, III, Chen L, Wu X, The interaction of CtIP and Nbs1 connects CDK and ATM to regulate HR-mediated double-strand break repair, PLoS Genet 9 (2013) e1003277.

[192] Uziel T, Lerenthal Y, Moyal L, Andegeko Y, Mittelman L, Shiloh Y, Requirement of the MRN complex for ATM activation by DNA damage, EMBO J 22 (2003) 5612-5621.

[193] Stracker TH, Petrini JH, The MRE11 complex: starting from the ends, Nat Rev Mol Cell Biol 12 (2011) 90-103.

[194] Kodama T, Takehara T, Hikita H, Shimizu S, Shigekawa M, Tsunematsu H, Li W, Miyagi T, Hosui A, Tatsumi T, Ishida H, Kanto T, Hiramatsu N, Kubota S, Takigawa M, Tomimaru Y, Tomokuni A, Nagano H, Doki Y, Mori M, Hayashi N, Increases in p53 expression induce CTGF synthesis by mouse and human hepatocytes and result in liver fibrosis in mice, J Clin Invest 121 (2011) 3343-3356.

[195] Yan HX, Wu HP, Zhang HL, Ashton C, Tong C, Wu H, Qian QJ, Wang HY, Ying QL, p53 promotes inflammation-associated hepatocarcinogenesis by inducing HMGB1 release, J Hepatol 59 (2013) 762-768.

[196] Bryant HE, Schultz N, Thomas HD, Parker KM, Flower D, Lopez E, Kyle S, Meuth M, Curtin NJ, Helleday T, Specific killing of BRCA2-deficient tumours with inhibitors of poly(ADP-ribose) polymerase, Nature 434 (2005) 913-917.

[197] McGlynn P, Lloyd RG, Recombinational repair and restart of damaged replication forks, Nat Rev Mol Cell Biol 3 (2002) 859-870.

[198] Michel B, Grompone G, Flores MJ, Bidnenko V, Multiple pathways process stalled replication forks, Proc Natl Acad Sci U S A 101 (2004) 12783-12788. 
[199] Haince JF, McDonald D, Rodrigue A, Dery U, Masson JY, Hendzel MJ, Poirier GG, PARP1dependent kinetics of recruitment of MRE11 and NBS1 proteins to multiple DNA damage sites, J Biol Chem 283 (2008) 1197-1208.

[200] Bryant HE, Petermann E, Schultz N, Jemth AS, Loseva O, Issaeva N, Johansson F, Fernandez S, McGlynn P, Helleday T, PARP is activated at stalled forks to mediate Mre11-dependent replication restart and recombination, EMBO J 28 (2009) 2601-2615.

[201] Galande S, Kohwi-Shigematsu T, Poly(ADP-ribose) polymerase and Ku autoantigen form a complex and synergistically bind to matrix attachment sequences, J Biol Chem 274 (1999) 20521-20528.

[202] Ariumi Y, Masutani M, Copeland TD, Mimori T, Sugimura T, Shimotohno K, Ueda K, Hatanaka $\mathrm{M}$, Noda M, Suppression of the poly(ADP-ribose) polymerase activity by DNA-dependent protein kinase in vitro, Oncogene 18 (1999) 4616-4625.

[203] Haince JF, Kozlov S, Dawson VL, Dawson TM, Hendzel MJ, Lavin MF, Poirier GG, Ataxia telangiectasia mutated (ATM) signaling network is modulated by a novel poly(ADP-ribose)dependent pathway in the early response to DNA-damaging agents, J Biol Chem 282 (2007) 16441-16453.

[204] Ko HL, Ren EC, Functional Aspects of PARP1 in DNA Repair and Transcription, Biomolecules 2 (2012) 524-548.

[205] Hassa PO, Hottiger MO, The diverse biological roles of mammalian PARPS, a small but powerful family of poly-ADP-ribose polymerases, Front Biosci 13 (2008) 3046-3082.

[206] Woodhouse BC, Dianov GL, Poly ADP-ribose polymerase-1: an international molecule of mystery, DNA Repair (Amst) 7 (2008) 1077-1086.

[207] Rodriguez-Vargas JM, Ruiz-Magana MJ, Ruiz-Ruiz C, Majuelos-Melguizo J, Peralta-Leal A, Rodriguez MI, Munoz-Gamez JA, de Almodovar MR, Siles E, Rivas AL, Jaattela M, Oliver FJ, ROS-induced DNA damage and PARP-1 are required for optimal induction of starvationinduced autophagy, Cell Res 22 (2012) 1181-1198.

[208] Szabo C, Roles of poly(ADP-ribose) polymerase activation in the pathogenesis of diabetes mellitus and its complications, Pharmacol Res 52 (2005) 60-71.

[209] Virag L, Poly(ADP-ribosyl)ation in asthma and other lung diseases, Pharmacol Res 52 (2005) 83-92.

[210] Szabo E, Kovacs I, Grune T, Haczku A, Virag L, PARP-1: a new player in the asthma field?, Allergy 66 (2011) 811-814.

[211] Pacher P, Szabo C, Role of poly(ADP-ribose) polymerase 1 (PARP-1) in cardiovascular diseases: the therapeutic potential of PARP inhibitors, Cardiovasc Drug Rev 25 (2007) 235260.

[212] Mukhopadhyay $P$, Rajesh $M$, Cao Z, Horvath B, Park O, Wang H, Erdelyi K, Holovac E, Wang $Y$, Liaudet L, Hamdaoui N, Lafdil F, Hasko G, Szabo C, Boulares AH, Gao B, Pacher P, Poly (ADPribose) polymerase-1 is a key mediator of liver inflammation and fibrosis, Hepatology(2013) 
[213] Wesierska-Gadek J, Schmid G, Poly(ADP-ribose) polymerase-1 regulates the stability of the wild-type p53 protein, Cell Mol Biol Lett 6 (2001) 117-140.

[214] Kameoka M, Ota K, Tetsuka T, Tanaka Y, Itaya A, Okamoto T, Yoshihara K, Evidence for regulation of NF-kappaB by poly(ADP-ribose) polymerase, Biochem J 346 Pt 3 (2000) 641649.

[215] Cazzalini O, Dona F, Savio M, Tillhon M, Maccario C, Perucca P, Stivala LA, Scovassi Al, Prosperi $\mathrm{E}, \mathrm{p} 21 \mathrm{CDKN} 1 \mathrm{~A}$ participates in base excision repair by regulating the activity of poly(ADP-ribose) polymerase-1, DNA Repair (Amst) 9 (2010) 627-635.

[216] Naura AS, Datta R, Hans CP, Zerfaoui M, Rezk BM, Errami Y, Oumouna M, Matrougui K, Boulares AH, Reciprocal regulation of iNOS and PARP-1 during allergen-induced eosinophilia, Eur Respir J 33 (2009) 252-262.

[217] Stilmann M, Hinz M, Arslan SC, Zimmer A, Schreiber V, Scheidereit C, A nuclear poly(ADPribose)-dependent signalosome confers DNA damage-induced IkappaB kinase activation, Mol Cell 36 (2009) 365-378.

[218] Oliver FJ, Menissier-de Murcia J, Nacci C, Decker P, Andriantsitohaina R, Muller S, de la RG, Stoclet JC, de Murcia G, Resistance to endotoxic shock as a consequence of defective NFkappaB activation in poly (ADP-ribose) polymerase-1 deficient mice, EMBO J 18 (1999) 44464454.

[219] Weaver AN, Yang ES, Beyond DNA Repair: Additional Functions of PARP-1 in Cancer, Front Oncol 3 (2013) 290.

[220] Smith GC, Jackson SP, The DNA-dependent protein kinase, Genes Dev 13 (1999) 916-934.

[221] Dip R, Naegeli $H$, More than just strand breaks: the recognition of structural DNA discontinuities by DNA-dependent protein kinase catalytic subunit, FASEB J 19 (2005) 704715.

[222] Koike M, Awaji T, Kataoka M, Tsujimoto G, Kartasova T, Koike A, Shiomi T, Differential subcellular localization of DNA-dependent protein kinase components Ku and DNA-PKcs during mitosis, J Cell Sci 112 ( Pt 22) (1999) 4031-4039.

[223] Nilsson A, Sirzen F, Lewensohn R, Wang N, Skog S, Cell cycle-dependent regulation of the DNA-dependent protein kinase, Cell Prolif 32 (1999) 239-248.

[224] Demangel C, Bertolino P, Britton WJ, Autocrine IL-10 impairs dendritic cell (DC)-derived immune responses to mycobacterial infection by suppressing DC trafficking to draining lymph nodes and local IL-12 production, Eur J Immunol 32 (2002) 994-1002.

[225] Calogero S, Grassi F, Aguzzi A, Voigtlander T, Ferrier P, Ferrari S, Bianchi ME, The lack of chromosomal protein Hmg1 does not disrupt cell growth but causes lethal hypoglycaemia in newborn mice, Nat Genet 22 (1999) 276-280.

[226] Topalova D, Ugrinova I, Pashev IG, Pasheva EA, HMGB1 protein inhibits DNA replication in vitro: a role of the acetylation and the acidic tail, Int J Biochem Cell Biol 40 (2008) 15361542. 
[227] Ugrinova I, Zlateva S, Pashev IG, Pasheva EA, Native HMGB1 protein inhibits repair of cisplatin-damaged nucleosomes in vitro, Int J Biochem Cell Biol 41 (2009) 1556-1562.

[228] Ugrinova I, Pashev IG, Pasheva EA, Nucleosome binding properties and Co-remodeling activities of native and in vivo acetylated HMGB-1 and HMGB-2 proteins, Biochemistry 48 (2009) 6502-6507.

[229] Lange SS, Mitchell DL, Vasquez KM, High mobility group protein B1 enhances DNA repair and chromatin modification after DNA damage, Proc Natl Acad Sci U S A 105 (2008) 1032010325.

[230] Liu Y, Prasad R, Wilson SH, HMGB1: roles in base excision repair and related function, Biochim Biophys Acta 1799 (2010) 119-130.

[231] Prasad R, Liu Y, Deterding LJ, Poltoratsky VP, Kedar PS, Horton JK, Kanno S, Asagoshi K, Hou EW, Khodyreva SN, Lavrik OI, Tomer KB, Yasui A, Wilson SH, HMGB1 is a cofactor in mammalian base excision repair, Mol Cell 27 (2007) 829-841.

[232] Yuan F, Gu L, Guo S, Wang C, Li GM, Evidence for involvement of HMGB1 protein in human DNA mismatch repair, J Biol Chem 279 (2004) 20935-20940.

[233] Yumoto $Y$, Shirakawa H, Yoshida M, Suwa A, Watanabe F, Teraoka H, High mobility group proteins 1 and 2 can function as DNA-binding regulatory components for DNA-dependent protein kinase in vitro, J Biochem 124 (1998) 519-527.

[234] Swanson PC, Fine structure and activity of discrete RAG-HMG complexes on V(D)J recombination signals, Mol Cell Biol 22 (2002) 1340-1351.

[235] Ohndorf UM, Rould MA, He Q, Pabo CO, Lippard SJ, Basis for recognition of cisplatinmodified DNA by high-mobility-group proteins, Nature 399 (1999) 708-712.

[236] Tang D, Kang R, Livesey KM, Cheh CW, Farkas A, Loughran P, Hoppe G, Bianchi ME, Tracey KJ, Zeh HJ, III, Lotze MT, Endogenous HMGB1 regulates autophagy, J Cell Biol 190 (2010) 881892.

[237] Gougeon ML, Bras M, Natural killer cells, dendritic cells, and the alarmin high-mobility group box 1 protein: a dangerous trio in HIV-1 infection?, Curr Opin HIV AIDS 6 (2011) 364-372.

[238] Ito I, Fukazawa J, Yoshida M, Post-translational methylation of high mobility group box 1 (HMGB1) causes its cytoplasmic localization in neutrophils, J Biol Chem 282 (2007) 1633616344.

[239] Degryse B, Bonaldi T, Scaffidi P, Muller S, Resnati M, Sanvito F, Arrigoni G, Bianchi ME, The high mobility group (HMG) boxes of the nuclear protein HMG1 induce chemotaxis and cytoskeleton reorganization in rat smooth muscle cells, J Cell Biol 152 (2001) 1197-1206.

[240] Andersson U, Wang H, Palmblad K, Aveberger AC, Bloom O, Erlandsson-Harris H, Janson A, Kokkola R, Zhang M, Yang $\mathrm{H}$, Tracey KJ, High mobility group 1 protein (HMG-1) stimulates proinflammatory cytokine synthesis in human monocytes, J Exp Med 192 (2000) 565-570.

[241] Sunden-Cullberg J, Norrby-Teglund A, Rouhiainen A, Rauvala H, Herman G, Tracey KJ, Lee $\mathrm{ML}$, Andersson J, Tokics L, Treutiger CJ, Persistent elevation of high mobility group box-1 
protein (HMGB1) in patients with severe sepsis and septic shock, Crit Care Med 33 (2005) 564-573.

[242] Kang R, Tang D, Schapiro NE, Loux T, Livesey KM, Billiar TR, Wang H, Van Houten B, Lotze MT, Zeh HJ, The HMGB1/RAGE inflammatory pathway promotes pancreatic tumor growth by regulating mitochondrial bioenergetics, Oncogene 33 (2014) 567-577. 